\author{
ارزيابى تحمل به شورى ارقام بومى خربزه ايرانى \\ هاجر شفيعى'، مريم حقيقى ץ* و على فرهادى \\ (تاريخ دريافت: 0 0
}

جִكيده

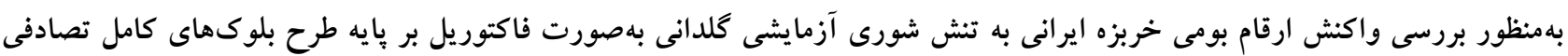

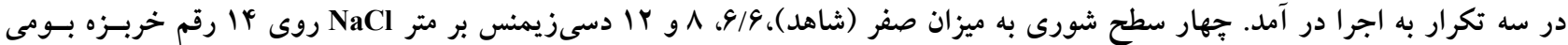

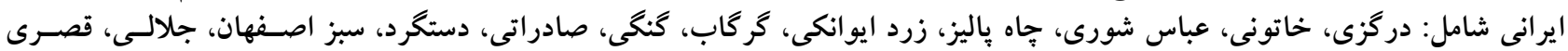

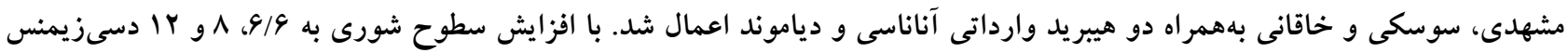

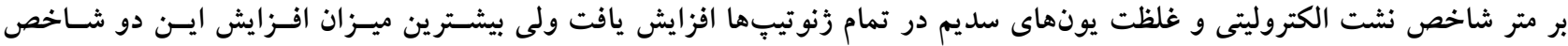

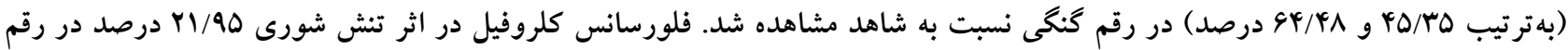

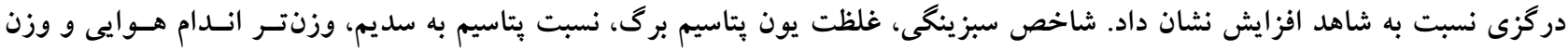

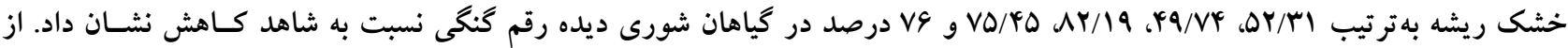

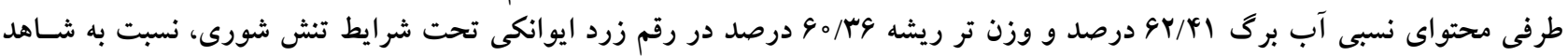

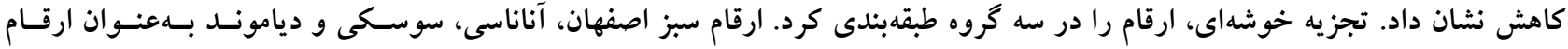

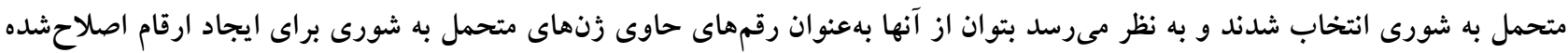

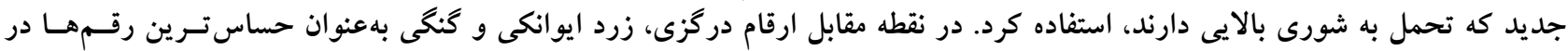

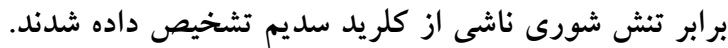

وازمهاى كليدى: نسبت يتاسيم به سديم، نشت يونى، وزن خشك

ا و r. بهترتيب دانشجوى كارشناسى ارشد و استاديار، گروه باغبانى، دانشكده كشاورزى، دانشگاه صنعتى اصفهان r. استاديار بخش تحقيقات گروه زراعى و باغى، مركز تحقيقات كشاورزى و منابع طبيعى اصفهان

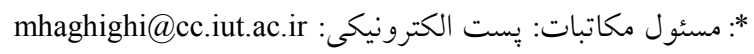


از تحقيقات انجام شده نشان داده است كه تحمـل بـه شـورى در

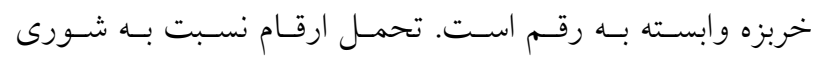

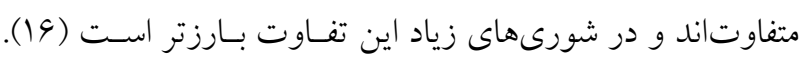

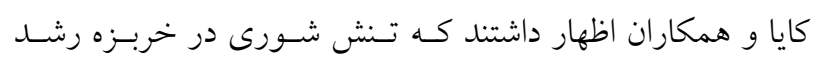

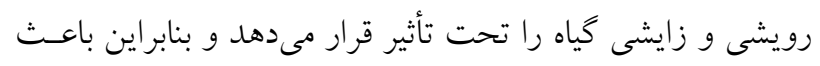

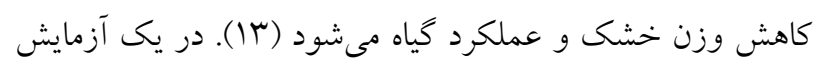
كلخانهاى كه اثر تنش شورى روى رشد و ميزان انباشـت يـونهــا

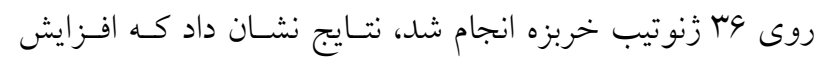

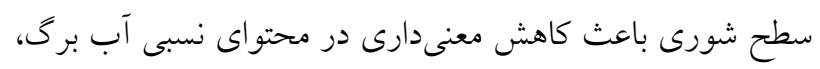

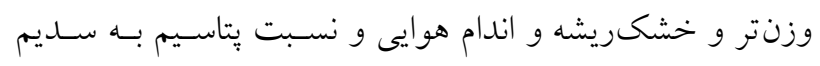

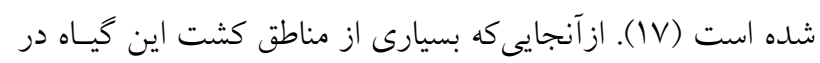

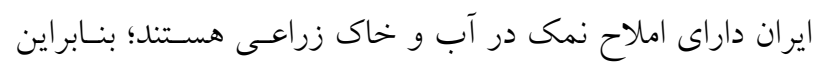

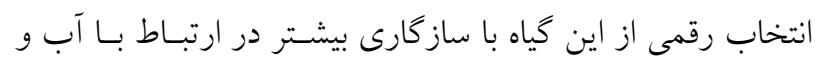

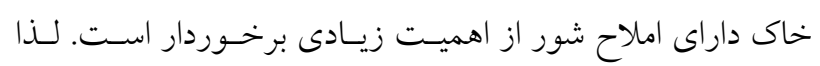

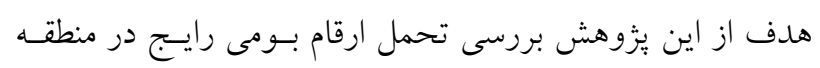

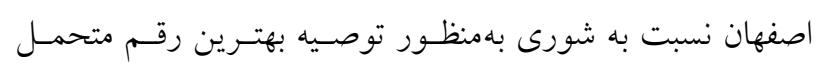

$$
\text { جهت كشت است. }
$$

\section{مواد و روشها}

در اين يُزوهش جهار سطح شورى: شـاهد (آب معمـولى)، ^،

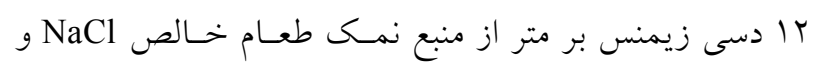

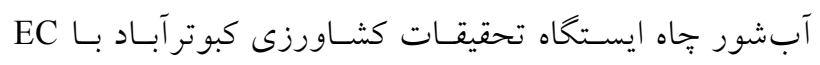

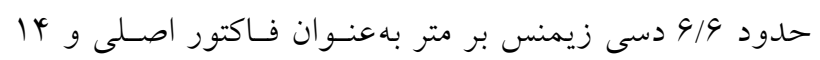

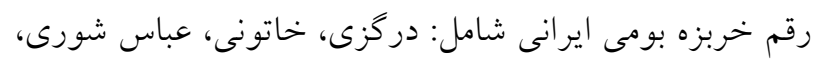

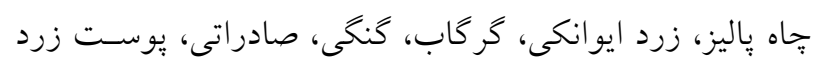

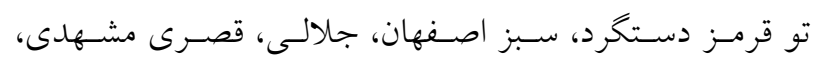

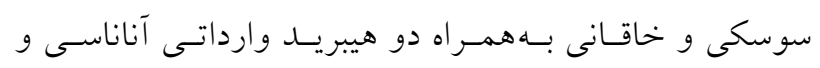

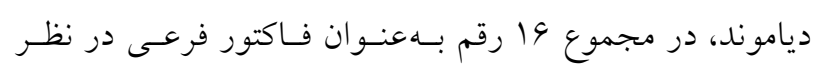

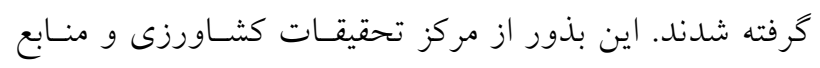

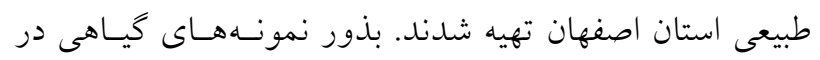

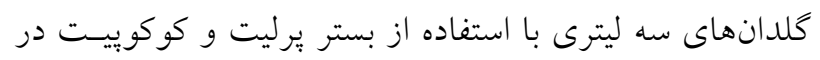

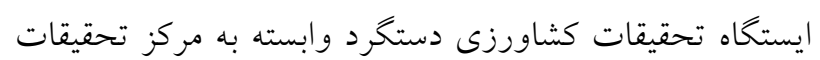

شورى يكى از مهمترين تنشهاى غير زنده و ازجمله عوامل مهـم

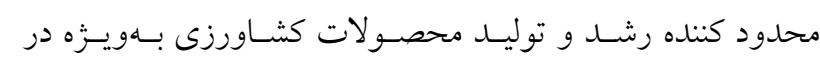
مناطق خشك و نيمه خشك جهان بهشـمار مسى آيـا (با). در حسال

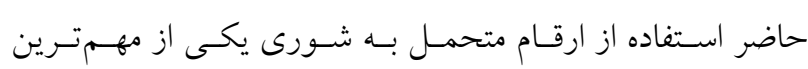

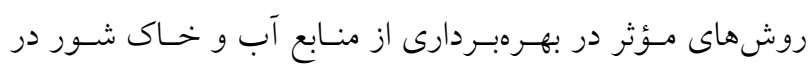

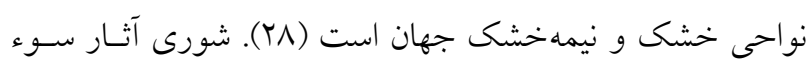

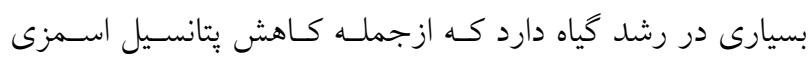

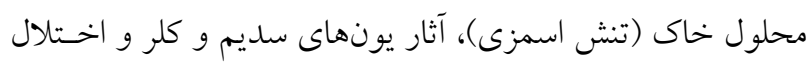

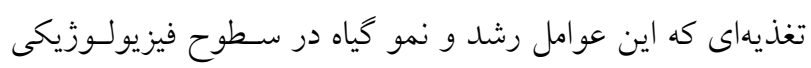

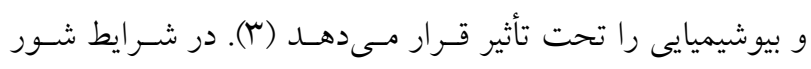

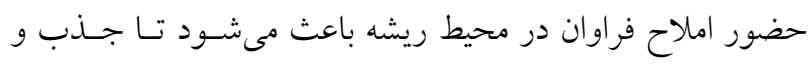

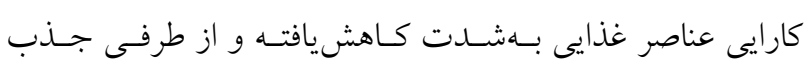
غيرضرورى بعضى از عناصر افزايش يابد و تركيب شيميايى كيـاه

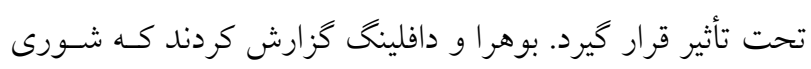

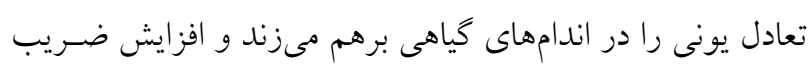

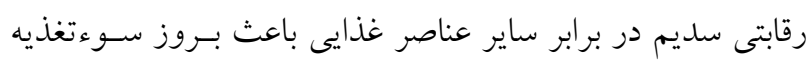
در كَاه مى

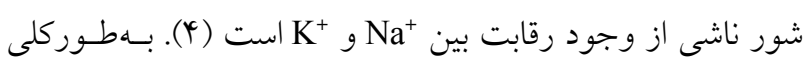

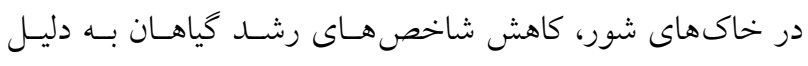

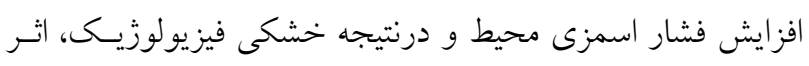

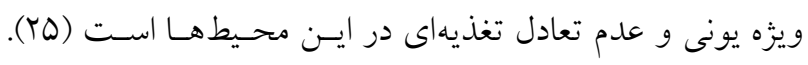

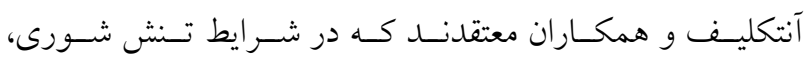
كونههايى كه توانايى بيشترى در محدود كردن تجمع نمـكهــا در

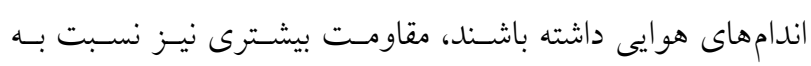

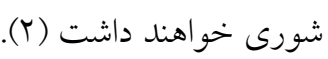

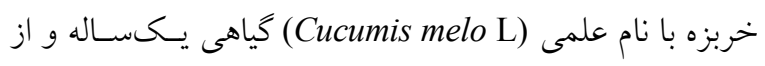

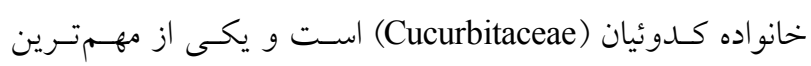
كياهان باغبانى است كه در بسيارى از مناطق خشك و نيمه خشكى

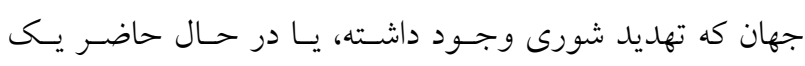

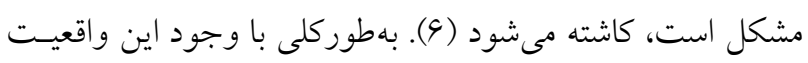

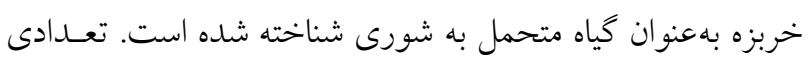


جوشيدن بود.

$\mathrm{EL}=\left(\mathrm{EC}_{1} / \mathrm{EC}_{Y}\right) \times 1 \circ 。$

\section{محتواى نسبى آب برى (RWC)} محتواى نسبى آب برى (RWC) مطابق روش ريجيى اندازهيـرى شد و از رابطه زير محاسبه و برحسب درصد بيان شد. $\mathrm{RWC}=(\mathrm{FW}-\mathrm{DW}) /(\mathrm{TW}-\mathrm{DW}) \times 1 \circ$ 。

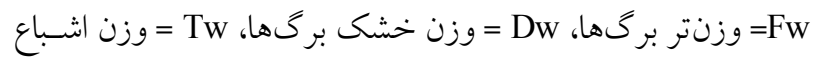
برگها (يس از Y M ساعت شناورى برگ در آب مقطر) است (Y)).

\section{شاخص سبزينگى} شاخص سبزينكى برى كياه كه نمايانگر ميـزان كلروفيـل بـرى است، توسـط دسـخاه كلروفيـل سـنجى (SPAD) مــل CL-01 ساخت كشور انخلستان، در سه برگ از برگهاى توسعهيافته هر

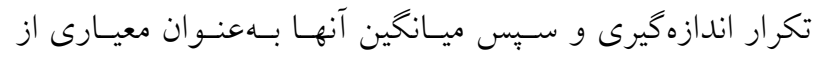
شاخص كلروفيل هر تكرار مدنظر قرار كرفت. نمونههاى برى گياه يس از خشك شدن بهوسيله انكوبـاتور

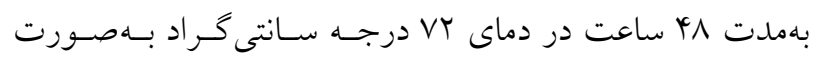

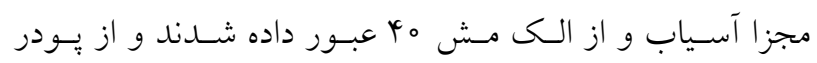
حاصله براى اندازهيرى يونهاى سديم و يتاسيم استفاده شد.

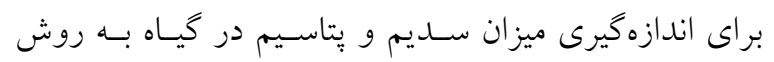

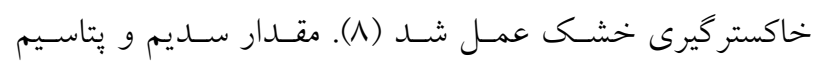
محلول بهوسيله دستخاه فليمفتومتر (مدل PFP7) اندازهگيـرى و مقدار آن با استفاده از منحنى استاندارد برحسـب ميلى گـرم در كرم وزن خشك محاسبه شد و در پيايان آزمـايش بوتـههـا را از محل طوقه جدا كرده و يس از شستشوى كامـل، بوتـههــا را در

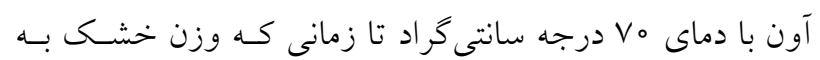
حالت ثبات رسيد، خشك كرده، سبس وزن تر و خشـى ريشـه

$$
\text { و اندام هوايى تعيين شد. }
$$

تجزيه واريانس و مقايسه ميانخينها بهروش آزمون حـداقل تفاوت معنى دار (LSD) در سطح احتمال ينج درصد بـا اسـتفاده

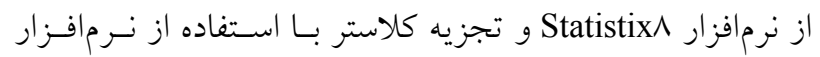
Statgraphics
و آموزش كشاورزى و منابع طبيعى اصفهان در يـك آزمـايش فاكتوريل در قالب طرح بلوى كامـل تصـادفى بـا سـه تكـــار كشت شدند. در هر تكرار دو گلدان و تعداد بوته در هر گلدان

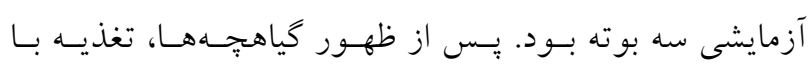

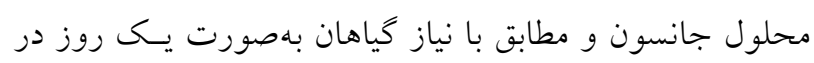

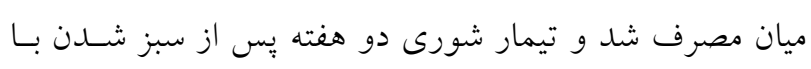
اضافه كردن سطوح شورى بـه محلـول جانسـون اعمـال شـــ. آبيارى با آب شور بهصورت زهآب انجام شد تا از تجمع نمى در داخل خاى جلو گيرى شود. به هر كلدان در هر بار اعمـال

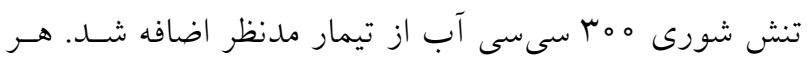

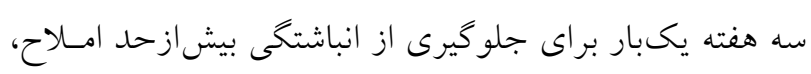

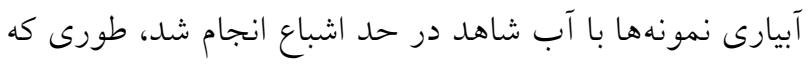
بهمضص خروج محلول از زير كلدانها كه نشاندهنـده اشـباع شدن بستر كشت است، آبيارى قطع شــ (Y) (I). بــراى آبيـارى

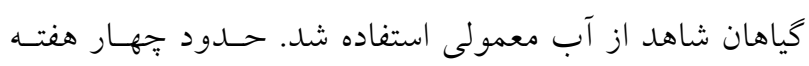

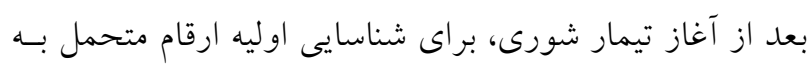
شورى صفات، فلورسانس كلروفيل، وزنتر و خشك اندامهاى

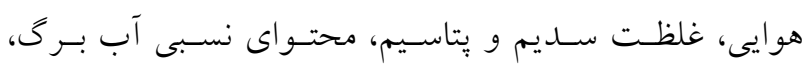
شاخص نشت الكتروليتى ارزيابى شد.

\section{فلورسانس كلروفيل}

فلورسانس كلروفيل توسط دستخاه فلورسانس كلروفيل (مـدل سـاخت كشـور انخلسـتان) در دو حالـت تـاريكى و روشنايى و با انتخاب جوانترين برى توسعه يافته و در مرحله

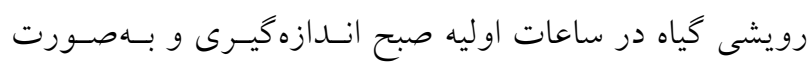

(Fv/Fm)

$$
\text { شاخص نشت الكتروليتى }
$$

اندازه كيرى شاخص نشت الكتروليتسى توسـط روش لوتسوس و همكاران انجام شد (19). درصد هدايت الكتريكى بيانكر ميـزان نشت الكتريكـى مــواد از غشـاء اسـت كـه مطـابق فرمــول زيــر محاسبه و برحسب درصد بيان شد. هدايت الكتريكى محلول ها بهترتيب قبل و بعـد از 


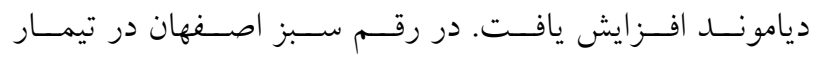
نتايج

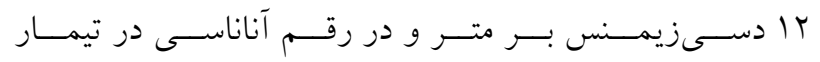
1 دسىزيمنس بر متر نسبت به شاهد افزايش معنى دارى را نشان

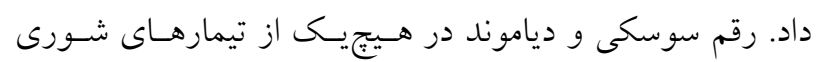

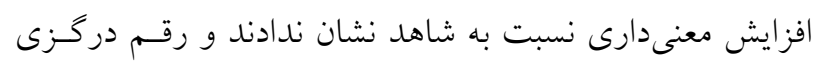
در تيمار 9/9 دسىزيمنس افزايش معنسى دارى نسـبت بـهـ تيمـار

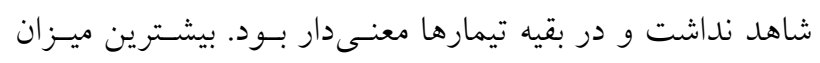
افزايش شاخص نشت الكتروليتى نسبت به شاهد بـه ارقـام زرد ايوانكى و كُنحى

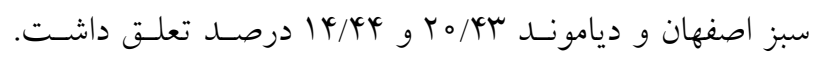

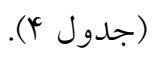
وزن تر اندام هـوايى بــا افزايش سـطوح شـورى در ارقـام

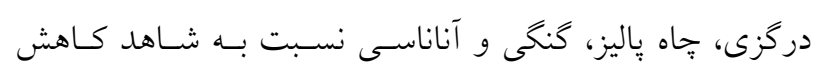

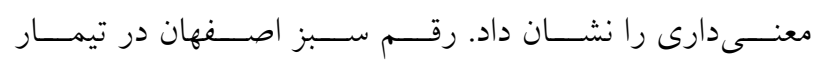

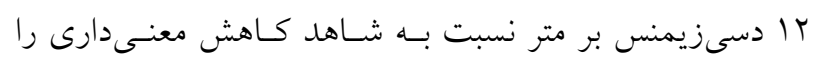

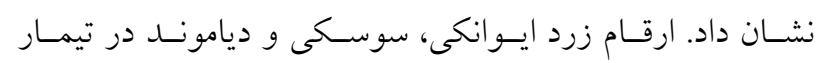
9/9 دسىزيمنس بر متر نسبت به شاهد كاهش معنى دارى نشـان

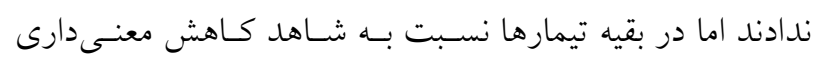
نشان دادند(جدول ه).

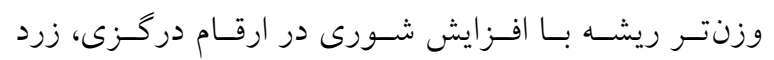
ايوانكى، كر كاب، كنگى، سبز اصفهان، جلالى و دياموند كـاهش

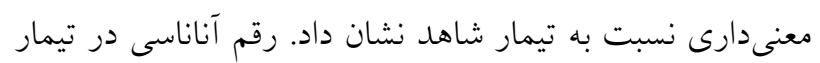

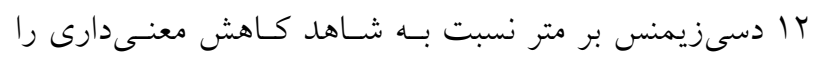
نشان داد. وزن خشك ريشه تحــت تــش شـورى در ارقـام زرد

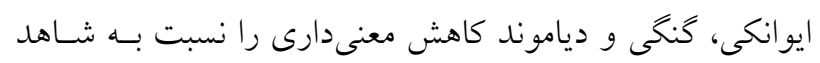

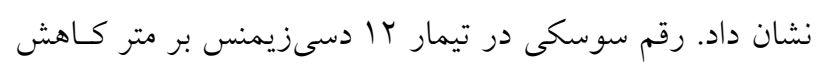

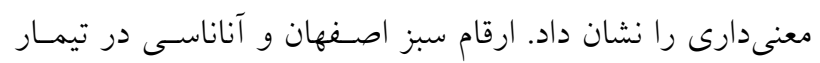

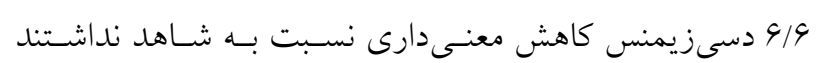

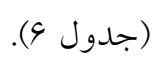

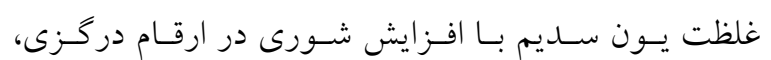

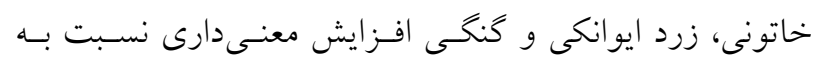

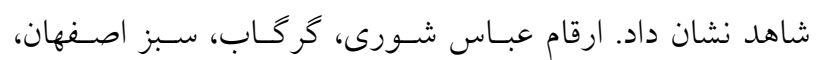

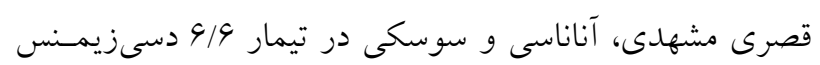
نتايج حاصل از تجزيه واريانس نشان داد، اثر متقابل رقم و شورى

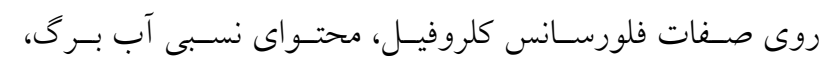

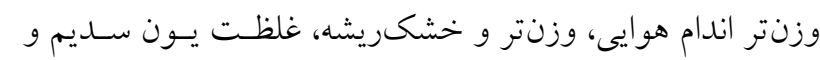

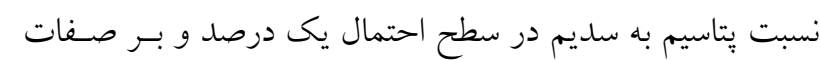

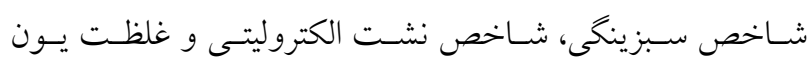

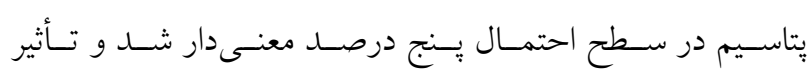

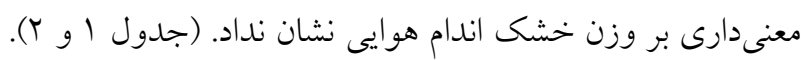

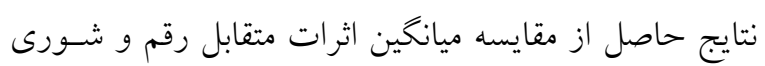

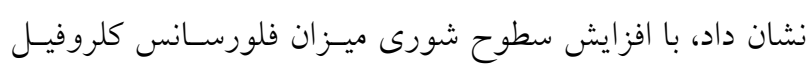

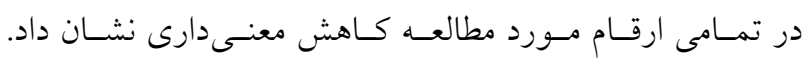

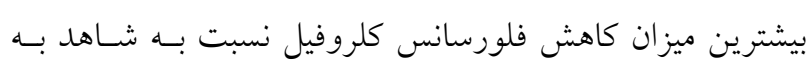

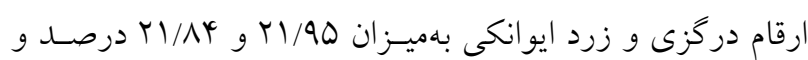

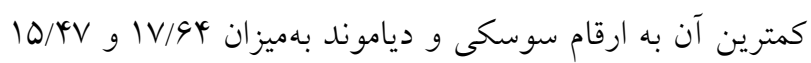
درصد تعلق داشت. در تيمار شاهد رقم سوسكى بيشترين ميزان

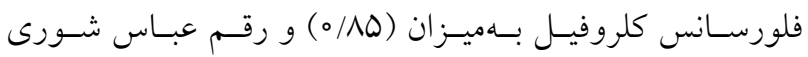

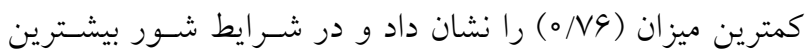

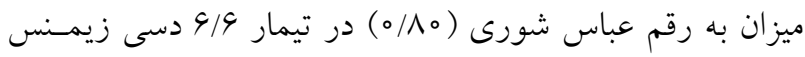

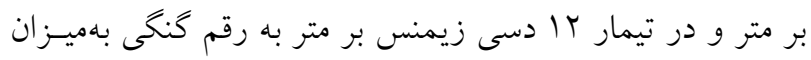

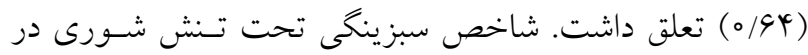

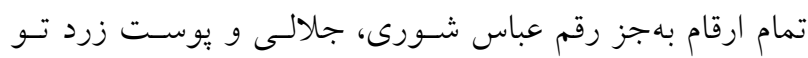

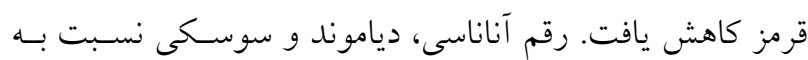
شاهد كاهش معنى دارى را نشان نداد (جدول بـ بم).

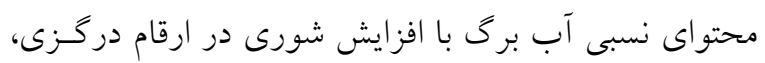

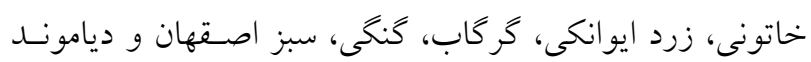

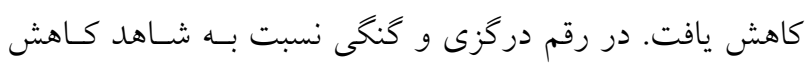

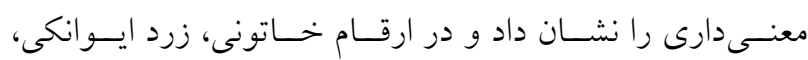

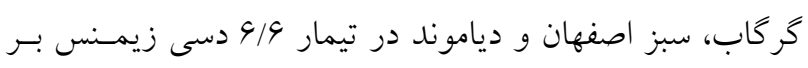

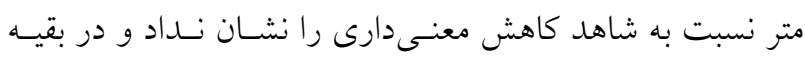
تيمارهاى شورى معنى دار بود.

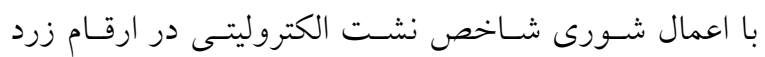

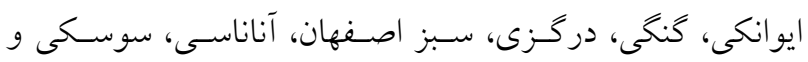


جدول ا. نتايج تجزيه واريانس اثر شورى و ارقام مختلف خربزه بر شاخص هاى فيزيولوزيكى

\begin{tabular}{|c|c|c|c|c|c|}
\hline شاخص نشت الكتروليتى & محتواى نسبى آب برگ & شاخص سبزينكى & فلورسانس كلروفيل & درجه آزادى & منابع تغييرات \\
\hline $\mid r V / \mu_{0}^{* *}$ & $1 \leftrightarrow N / 99^{* *}$ & $\mu \psi / \mu V^{* *}$ & $0 / 0019^{* *}$ & 10 & رقم \\
\hline$\varphi 99 / 99^{* *}$ & $10 \circ \Lambda /\left.4\right|^{* *}$ & $10 r / 9 V^{* *}$ & $\circ / 0 \circ 9 \mu^{* *}$ & r & 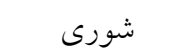 \\
\hline $4 \& / 01^{*}$ & $110 / \wedge r^{* *}$ & $\Gamma / 90^{*}$ & $\circ / \circ \circ \circ V^{* *}$ & id & ل \\
\hline 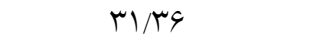 & $\varphi \wedge / \mu V$ & $T / \Delta \Lambda$ & $\circ / 0 \circ \circ \mu$ & IrG & خطا \\
\hline $19 / T Y^{4}$ & T & 19/AT & $T / \mathcal{E V}$ & & ضريب تغييرات \\
\hline
\end{tabular}

جدول r. نتايج تجزيه واريانس اثر شورى و ارقام مختلف خربزه بر شاخصهاى رشدى و غلظت عناصر

\begin{tabular}{|c|c|c|c|c|c|c|c|c|}
\hline يتاسيم به سديم & سديم & يتاسيم & وزن خشك ريشه & وزنام خشام هوايى & رزنة & اندام هو ايى & آزادى درجه & منابع تغييرات \\
\hline$\circ / 1 r^{* *}$ & $144 / 19^{* *}$ & $9 r / V^{* * *}$ & $\circ / \Delta \Lambda^{* *}$ & $9 / 0)^{* *}$ & $9 / Y Y^{* *}$ & $r V I / I I^{* *}$ & 10 & رقم \\
\hline $0 / 01^{* *}$ & $\Delta V \& \Psi / \Delta Y^{* *}$ & ITAY/DG** & $\circ / 19^{* *}$ & $\mid Y \wedge / Y \Lambda^{* *}$ & $\Pi / \Delta \Delta^{* *}$ & $\Gamma \wedge \vee \Delta / ৭ Q^{* *}$ & r & شورى \\
\hline$\circ / 1^{* *}$ & $\| \omega / q r^{* *}$ & $\psi v^{*}$ & $\circ / \circ Q^{* *}$ & $1 / 9 r^{\mathrm{ns}}$ & $\Gamma / \mu I^{* *}$ & $101 / 9 r^{* *}$ & Ya & رقم × شورى \\
\hline$\circ / \circ 0$ & $F T / Y Y$ & MIVQ & $0 / 01$ & $1 / 09$ & $1 / \Gamma \Lambda$ & $v q / l^{c}$ & $1 K 4$ & خطا \\
\hline$r \& / \mu \circ$ & $19 / 49$ & $1 N / I V$ & YO/ KY & $11 / 9 V$ & TY/TY & $I V / T Y$ & & ضريب تغييرات \\
\hline
\end{tabular}
ns غير معنى دار،* و ** بهترتيب معنى دار در سطح احتمال ينج و يك درصد

جدول r. نتايج مقايسه ميانگين اثر متقابل شورى و ارقام مختلف خربزه بر فلورسانس كلروفيل و شاخص سبزينگى

\begin{tabular}{|c|c|c|c|c|c|c|c|c|}
\hline \multirow{2}{*}{\multicolumn{4}{|c|}{ شاخص سبزينخى (SPAD) شورى (dS m }} & \multicolumn{5}{|c|}{ فلورسانس كلروفيل } \\
\hline & & & & \multirow[b]{2}{*}{ ir } & \multicolumn{4}{|c|}{ شورى (dS m } \\
\hline ir & $\wedge$ & $9 / 9$ & صفر & & $\wedge$ & $9 / 9$ & صفر & | - ارقام \\
\hline$Q / / \& \mathrm{yz}$ & $\mathrm{V} / \circ \wedge^{t-y}$ & $V / V Y^{s-y}$ & $q / V Q g-s$ & $0 / 94 \mathrm{y}$ & $0 / 9 q^{u-w}$ & $\circ / V Q^{1-0}$ & o/AY ${ }^{\mathrm{b}-\mathrm{f}}$ & درگزى \\
\hline$N / \Delta \varphi^{1-w}$ & $q / \wedge \vee^{g-r}$ & $Q / Y^{\prime}{ }^{h-u}$ & $1 r / \mathrm{V} \Lambda^{\mathrm{a}-\mathrm{c}}$ & $\circ / 9 \wedge \mathrm{wx}$ & $\circ / V^{s-w}$ & $\circ / V^{h-1}$ & $\circ / \Lambda r^{a-d}$ & خاتونى \\
\hline$\Lambda / T^{\mathrm{n}-\mathrm{x}}$ & $9 / 9 \mu^{\mathrm{v}-\mathrm{z}}$ & $9 / T^{\text {h-u }}$ & $11 / 9 \mu^{\mathrm{c}-1}$ & $0 / 9 \Lambda^{v-x}$ & $\circ / V_{0} \mathrm{r}-\mathrm{s}$ & $\circ / \Lambda^{e-h}$ & $\circ / V q^{i-m}$ & عباس شورى \\
\hline$\Lambda / T^{\mathrm{m}-\mathrm{w}}$ & $10 / \Lambda^{d-m}$ & $\mid r / 4 V^{b-f}$ & $9 / 99 \mathrm{g-t}$ & $\circ / V \cdot r-w$ & $\circ / N r^{n-r}$ & $\circ / N{ }^{q m-p}$ & $\circ / N q^{f-j}$ & جاه ي باليز \\
\hline $0 / 90^{x-z}$ & $\Lambda / \circ \mu^{p-x}$ & $\Lambda / T^{\mathrm{n}-\mathrm{x}}$ & $10 / \wedge 9^{d-1}$ & $0 / 99 x y$ & $0 / 99^{u-x}$ & $\circ / V Q^{k-n}$ & $0 / \Lambda K^{a-c}$ & زرد ايوانكى \\
\hline $9 / Y^{\mathrm{w}-\mathrm{z}}$ & $10 /\left.0\right|^{f-r}$ & $V / 4 q^{r-y}$ & $10 / 9 y^{\mathrm{d}-0}$ & $0 / 99 v-x$ & $\circ / V^{s-w}$ & $\circ / \sqrt{ } y^{j-m}$ & $\circ / \Lambda 0^{e-h}$ & كرگاب \\
\hline$Y / T r^{z}$ & $9 / \mathrm{VV} \mathrm{u}-\mathrm{z}$ & $\Lambda / 4 \varphi^{1-w}$ & $\Lambda / \wedge \Delta^{j-v}$ & $0 / 94 \mathrm{y}$ & $0 / 99$ t-w & $\circ / \sqrt{ } q^{j-m}$ & $0 / \Lambda r^{a-e}$ & كنگ \\
\hline$V / 1^{t-y}$ & $V / 19^{s-y}$ & $9 / 1 r^{i-v}$ & $10 / 9 r^{\mathrm{d}-1}$ & $0 / 9 \Lambda^{v-x}$ & $\circ / V^{\mathrm{s}-\mathrm{w}}$ & $\circ / V \wedge{ }^{g-k}$ & $\circ / \Lambda)^{c-g}$ & صادراتى \\
\hline $10 / \pi r^{f-q}$ & $N / r^{m-x}$ & $10 / 0$ fe-p $^{\alpha}$ & $|1 / \mathrm{A}|^{\mathrm{b}-\mathrm{h}}$ & $0 / 99^{\mathrm{t}-\mathrm{w}}$ & $\circ / N F^{\mathrm{m}-\mathrm{q}}$ & $\circ / V^{h-1}$ & $\circ / \Lambda r^{\mathrm{a}-\mathrm{d}}$ & يوست زرد \\
\hline$\Lambda / \circ \Delta^{0-x}$ & $N / Y^{\mathrm{m}-\mathrm{x}}$ & $9 / 01^{j-v}$ & $\mid r / \circ V^{b-g}$ & $\circ / 0^{s-w}$ & $\circ / V \backslash^{q-v}$ & $\circ / \sqrt{ } \varphi^{j-m}$ & $\circ / \Lambda F^{a b}$ & سبز اصفهان \\
\hline $1 / 19^{0-x}$ & $V / V^{q-y}$ & $\Lambda / 1^{0-x}$ & $\mid r / I Y^{\mathrm{b}-\mathrm{e}}$ & $0 / 9 \wedge v-x$ & $\circ / V Y^{0-t}$ & $\circ / V \varphi^{i-m}$ & $\circ / \Lambda \circ d-g$ & جلالى \\
\hline $9 / 911^{u-y}$ & $V / 90 Q^{q-y}$ & $9 / \wedge \vee^{g-r}$ & $\Lambda / \vee q^{k-w}$ & $\circ / V^{r-w}$ & $\circ /\left.V\right|^{q-v}$ & $\circ / V^{\mathrm{k}-\mathrm{m}}$ & $\circ / \Lambda Y^{b-f}$ & قصرى مشهلى \\
\hline$\| /\left.T\right|^{c-k}$ & $11 / k \mu^{c-j}$ & $11 / 9 V^{c-i}$ & $\mid r / \Delta \Lambda^{a-c}$ & $\circ / V Y^{0-t}$ & $\circ / r^{n-s}$ & $\circ / V q^{e-i}$ & $\circ / \wedge \Delta^{a b}$ & آناناسى \\
\hline$|1 / N|^{c-i}$ & $\mid r / \& q^{b-f}$ & $1 \% / r^{b-d}$ & $1 \pi / N^{a-c}$ & $\circ / V o^{r-w}$ & $o / V Y^{0-t}$ & $\circ / \Lambda 0^{e-h}$ & $\circ / \wedge \Delta^{a}$ & سوسكى \\
\hline$V / 19$ s-y & $V / V^{q-x}$ & $\Lambda / \backslash \wedge^{0-x}$ & $\Lambda / \mu^{\prime}$ l-w & $\circ / V 0^{r-w}$ & $\circ / V \circ{ }^{r-w}$ & $\circ / \sqrt{ } \varphi^{i-m}$ & $\circ / \Lambda)^{c-g}$ & خاقانى \\
\hline \multirow[t]{2}{*}{$1 \circ / N \Lambda^{\mathrm{d}-\mathrm{n}}$} & $\mid \Psi / \mu^{a b}$ & $1 \% / r^{b-d}$ & $19 / 10^{a}$ & $\circ / N)^{q-v}$ & $\circ / V Y^{p-u}$ & $\circ / \vee q g-j$ & $0 / \wedge f a b$ & دياموند \\
\hline & $r / 09$ & & & & $\circ / 0 r$ & & & $\mathrm{LSD}_{\% 5}$ \\
\hline
\end{tabular}

در هر ستون ميانكينهايى كه داراى حداقل يكى حرف مشترى هستند، تفاوت معنى دارى در سطح احتمال ينج درصد بر اساس آزمون حداقل اختلاف معنىدار (LSD)، ندارند. 
نشريه توليد و فرآورى محصولات زراعى و باغى / سال نهم / شماره اول / بهار 1ra1

جدول f. نتايج مقايسه ميانخين اثر متقابل شورى و ارقام مختلف خربزه بر محتواى نسبى آب برى و شاخص نشت الكتروليتى

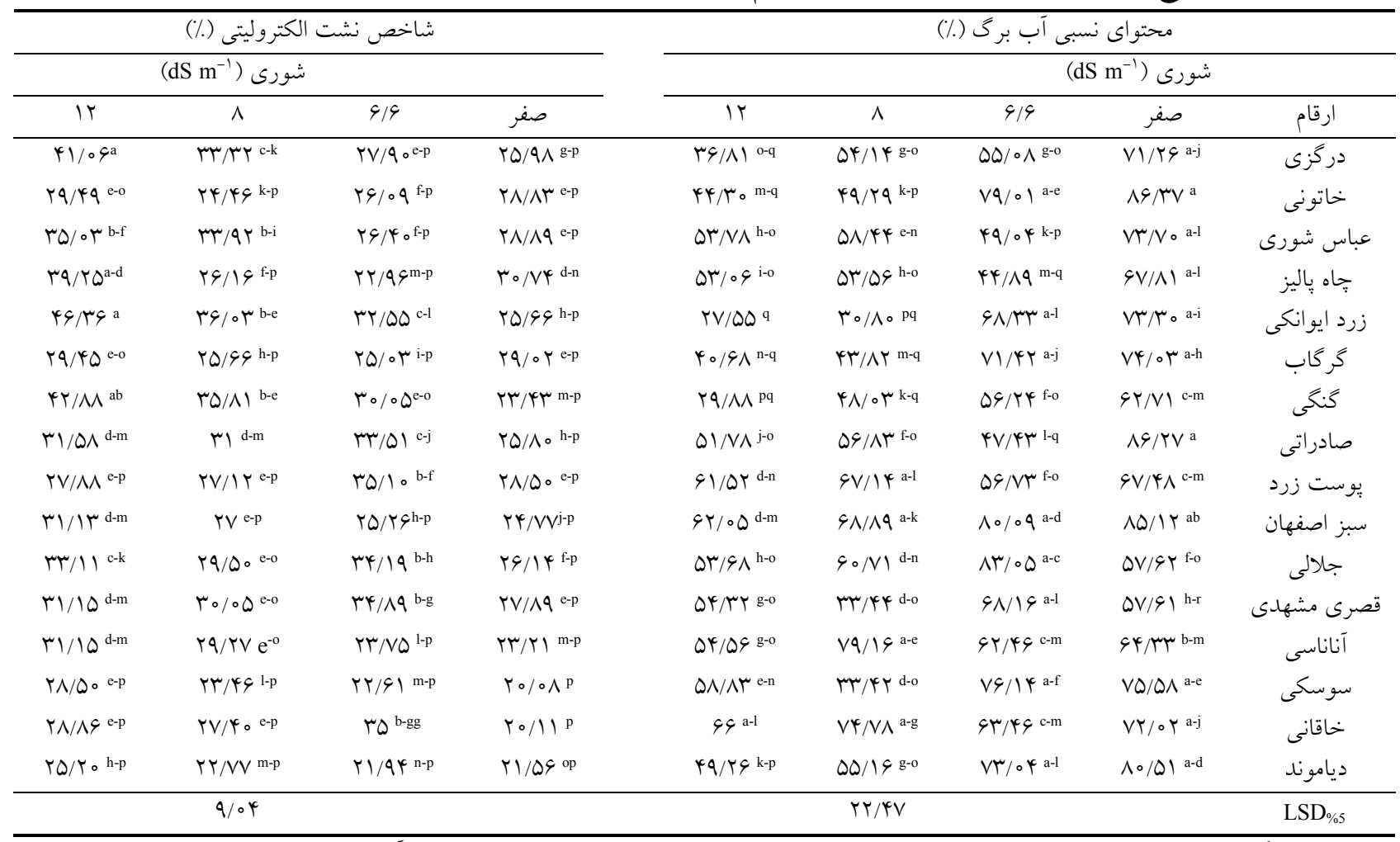

در هر ستون ميانخينهايى كه داراى حداقل يكى حرف مشترى هستند تفاوت معنى دارى در سطح احتمال بِنج درصد بر اساس آزمون حداقل اختلاف معنىدار (LSD)، ندارند.

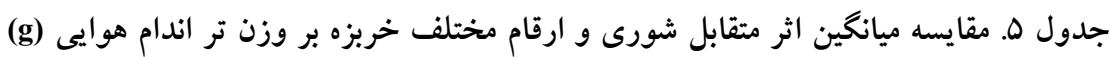

\begin{tabular}{|c|c|c|c|c|}
\hline \multicolumn{5}{|c|}{ شورى ( (dS m) } \\
\hline Ir & $\wedge$ & $9 / 9$ & صفر & ارقام \\
\hline$r \Lambda / Y V^{w-y}$ & $\kappa \mu / \psi^{*} V^{n-v}$ & $\Delta \psi / T \Delta^{b-r}$ & $94 / 1 y^{\mathrm{a}-\mathrm{f}}$ & درگزى \\
\hline$M / 9 Y^{v-y}$ & $F \vee / 9 \wedge j-t$ & $\Delta \mathcal{G} / \mathrm{V}^{\mathrm{b}-\mathrm{o}}$ & $\Delta r / q \mu^{c}-\mathrm{r}$ & خاتونى \\
\hline$Y \circ / T Q^{r-y}$ & $\Delta r / \Lambda V^{d-s}$ & $Y \wedge /\left.V\right|^{h-t}$ & $G \mu / \mathcal{Y} \wedge^{\mathrm{a}-\mathrm{g}}$ & عباس شورى \\
\hline 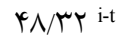 & $\Delta \circ / V \backslash^{f-t}$ & $\Delta Y / \circ V^{c-r}$ & $\Delta Q / \Delta \& b-k$ & جاه ياليز \\
\hline$\curlyvee \vee / \backslash \wedge x y$ & $c r / \mu v^{n-v}$ & $\Delta V / \mu Y^{b-n}$ & $\Delta \wedge / T \wedge \mathrm{b}-1$ & زرد ايوانكى \\
\hline$r_{0} / / \varphi^{\mathrm{u}-\mathrm{y}}$ & $4 y / 19^{1-u}$ & $\Delta r / \circ V^{c-r}$ & $01 / Y^{\mathrm{f}-\mathrm{t}}$ & كر گاب \\
\hline rG/Ay & CY/TV o-w & $\Delta Y / / \Delta^{b-r}$ & $9 r / 99^{a-h}$ & كنگ \\
\hline YN/AY w-y & OV/NG b-n & $9 \circ / 9^{a-k}$ & $09 / \circ Q$ b-o & صادراتى \\
\hline r/D| s-y & $p q /\left.0\right|^{h-t}$ & 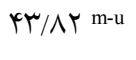 & $91 / 1 \mu^{a-k}$ & يوست زرد \\
\hline$\Delta Q / \Delta \vee b-p$ & $9 Y / 99^{a-h}$ & $90 / 91$ a-e & $49 / 4 \wedge{ }^{\mathrm{a}-\mathrm{d}}$ & سبز اصفهان \\
\hline $49 / 21^{g-t}$ & $\Delta F / q V^{b-q}$ & $G Y / \circ \mu^{a-j}$ & $\Psi \vee / \varphi \wedge k-t$ & جالى \\
\hline 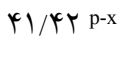 & $91 / 01^{\mathrm{a}-\mathrm{k}}$ & rV/VYt-u & $V Y^{\mathbb{N}} / \mathrm{A}^{\mathrm{a}}$ & قصرى مشهلدى \\
\hline $\mathrm{F} / \mathrm{Q}^{\mathrm{k}-\mathrm{t}}$ & $01 / 99 \mathrm{e}-\mathrm{t}$ & $\Delta N / I Y^{b-m}$ & $G Y / 0 r^{a-j}$ & آناناسى \\
\hline$\varphi_{\circ} / \Lambda \mu^{q-y}$ & $F V / q q^{\mathrm{j}-\mathrm{t}}$ & $90 / 09 \mathrm{a-k}$ & $q V / \mu V^{a-c}$ & سوسكى \\
\hline$\uparrow \wedge / 90^{\mathrm{h}-\mathrm{t}}$ & $\Delta \wedge / 9 \mid b-k$ & $\Delta G / Y^{b-o}$ & $0 \circ / 0 \nvdash \mathrm{f}-\mathrm{t}$ & خاقانى \\
\hline$Y \wedge / Y^{\prime} \xi^{j-t}$ & $\Delta \circ / T \Delta \mathrm{f}-\mathrm{t}$ & $9 Y / 99$ a-i & $9 \wedge / 0^{\mathrm{ab}}$ & دياموند \\
\hline & & $14 / T V$ & & $\mathrm{LSD}_{\% 5}$ \\
\hline
\end{tabular}

در هر ستون ميانكين هايى كه داراى حداقل يكى حرف مشترك هستند، تفاوت معنى دارى در سطح احتمال ينج درصد بر اساس آزمون حداقل اختلاف معنىدار (LSD)، ندارند. 
جدول 9. نتايج مقايسه ميانگين اثر متقابل شورى و ارقام مختلف خربزه بر وزن تر و خشك ريشه

\begin{tabular}{|c|c|c|c|c|c|c|c|c|}
\hline \multicolumn{4}{|c|}{ وزن خشكريشه (g) } & \multicolumn{4}{|c|}{ وزنتر ريشه (g) } & \\
\hline \multicolumn{4}{|c|}{ شورى (dS m } & & \multicolumn{4}{|c|}{ شورى (dS m } \\
\hline ir & $\wedge$ & $9 / 9$ & صفر & ir & $\wedge$ & $9 / 9$ & صفر & ارقام \\
\hline $0 / Y^{x}$ & $0 /$ My s-x & $\circ / \mu \wedge$ n-w & $0 / Y^{*} y^{1-t}$ & $r / 4 q p-r$ & $r / \Lambda^{i-r}$ & $Y / T q$ g-p & $\Delta / \Delta q^{b-k}$ & درگزى \\
\hline$\circ /\left.D\right|^{j-s}$ & $\circ / 0^{j-s}$ & $\circ / \Delta Y^{i-r}$ & $0 / F^{*} \varphi^{1-u}$ & $r / \Gamma q q \mathrm{q}$ & $Y / \Delta q^{f-n}$ & $Y / Y V^{f-n}$ & $\varphi / \backslash \wedge^{g-q}$ & خاتونى \\
\hline$\circ / Y^{4} \mathrm{~m}-\mathrm{v}$ & $\circ / \mu V^{o-w}$ & $\circ / V G c-f$ & $\circ /\left.D\right|^{j-s}$ & n-r & $\Delta / 9 r^{a-g}$ & $\mathrm{Q} / 19 \mathrm{c}-\mathrm{m}$ & $r / M \mu g-q$ & عباس شورى \\
\hline$\circ / \Delta \wedge \mathrm{g}-\mathrm{m}$ & $\circ / \Gamma \Delta^{r-x}$ & $\circ / Y Q^{1-t}$ & $\circ / \Delta r^{i-p}$ & $r / \circ q^{r}$ & $Y / V V^{e-n}$ & $Y / 0^{g-n}$ & $\varphi / \Delta^{g-n}$ & جّاه يّاليز \\
\hline$\circ / Y I$ wx & $\circ / \mu V^{o-w}$ & $\circ / 4 \wedge^{1-\mathrm{s}}$ & $0 / 99 \mathrm{e}-\mathrm{j}$ & $\mathrm{r} / 19 \mathrm{r}$ & $r / r V^{n-r}$ & $\varphi / \mu_{q} g-0$ & $\Delta / 4 \Delta \mathrm{c}-\mathrm{k}$ & زرد ايو انكى \\
\hline$\circ / Y y w x$ & $0 / \mu_{4}$ q-x & $\circ / 09 \mathrm{f}-1$ & $\circ / \Delta \wedge g^{-m}$ & $r / \Delta V^{m-r}$ & $\varphi / \circ \Delta^{h-q}$ & $p / x^{<} \mathbb{g}^{\mathrm{g}-\mathrm{o}}$ & $\varphi / V^{f-n}$ & كر گاب \\
\hline$\circ / Y I$ wx & $\circ / Y V^{u-x}$ & $\circ / \Gamma \Delta^{r-x}$ & $\circ / \wedge 9 b c$ & r/GY o-r & $r / Y Y^{n-r}$ & $r / \circ r^{h-q}$ & $4 / 90^{\mathrm{a}-\mathrm{d}}$ & كَن \\
\hline$\circ \mu \Delta^{s-x}$ & $\circ / \Psi_{Y} \mathcal{C}^{1-u}$ & $\circ / \Delta \Delta^{h-n}$ & $0 / 4 \varphi^{1-t}$ & P/Fg-o & $\Gamma / \Lambda \kappa^{j-r}$ & $\Delta / Y Y^{c-m}$ & $r / N V^{k-r}$ & صادراتى \\
\hline $0 / Y^{a-v}$ & $\circ / \Delta \mu^{i-q}$ & $0 / \mu^{p-x}$ & $\circ / V^{c-e}$ & $\Gamma / \Lambda \Gamma^{j-r}$ & $r / Y^{n-r}$ & $Y / \Delta Y^{g-n}$ & $V / T q a b$ & يوست زرد \\
\hline$\circ / \mu^{n}$ n-w & $\circ / \Delta^{j-s}$ & $o / \Delta Y^{h-n}$ & $\circ / V^{d-h}$ & $\psi^{\mathrm{h}-\mathrm{q}}$ & $Y / T Q^{g-p}$ & $Y / V^{f-n}$ & $\Delta / \uparrow^{c-m}$ & سبز اصفهان \\
\hline$\circ / T V^{v-x}$ & $\circ / D Y$ i-o & 0 & $\circ / D Y^{\mathrm{h}-\mathrm{n}}$ & $r / 09^{1-r}$ & $\varphi / / \varphi^{q-q}$ & $\boldsymbol{y} /\left.\mu\right|^{\mathrm{g}-\mathrm{b}}$ & $q / \mu q$ a-f & جالى \\
\hline $0 / Y^{t-x}$ & $\circ / V^{0-w}$ & $1 / \circ \wedge^{a}$ & $\circ / \Delta r^{i-p}$ & $\mathrm{r} / \wedge^{\mathrm{j}-\mathrm{r}}$ & $9 / 00^{\mathrm{a}-\mathrm{e}}$ & $r / \Lambda r^{j-r}$ & $Q / 9 Y^{b-j}$ & قصرى مشهلدى \\
\hline ०/D९ g-m & $\circ / V Y^{\mathrm{c}-\mathrm{g}}$ & $\circ / V^{c-e}$ & $\circ / \wedge r^{b-e}$ & $\Delta / \uparrow^{c-m}$ & Q/AY a-h & $G / V^{\mathrm{a}-\mathrm{d}}$ & $V / T^{a b}$ & آناناسى \\
\hline$\circ / V^{c-e}$ & ॰/^૬ b-d & $\circ / 9 y^{a b}$ & $\circ / 9 \mathrm{Vab}$ & $Y / \mu V^{g-o}$ & $r /\left.9\right|^{f-n}$ & $V / G y^{a}$ & $\Delta / 9 Y^{\mathrm{a}-\mathrm{g}}$ & \\
\hline $0 / 4 \Delta^{1-t}$ & $0 / 49 \mathrm{k}-\mathrm{s}$ & $0 / 99 \mathrm{~d}-1$ & $\circ / \Delta \Delta^{g-m}$ & $\varphi / \mu^{g-o}$ & $\Delta / 4 \varphi c c k$ & G/Na ${ }^{a-c}$ & $\Delta / V \backslash^{b-i}$ & خاقانى \\
\hline \multirow[t]{2}{*}{$0 / 41 \mathrm{~m}-\mathrm{v}$} & $0 / 4 Q^{1-t}$ & $\circ / \Delta q^{f-1}$ & $0 / 90 \mathrm{e}-\mathrm{k}$ & $Y / 9 \Delta^{d-n}$ & سח/ c-m & $\Delta / Y^{c} Y^{c-1}$ & $\Delta / \wedge^{b-h}$ & دياموند \\
\hline & $\circ / I V$ & & & & & l/Ar & & $\mathrm{LSD} \% 5$ \\
\hline
\end{tabular}

در هر ستون ميانكينهايى كه داراى حداقل يكى حرف مشترى هستند، تفاوت معنى دارى در سطح احتمال بنج درصد بر اساس أزمون حداقل اختلاف معنىدار (LSD)، ندارند.

به سديم تحت تنش شورى در ارقام درگـزى، خـاتونى، عبـاس شورى، زرد ايوانكى، كنخـى، سـبز اصـفهان، قصسرى مشـهـى، آناناسى، سوسكى و دياموند نسبت به شاهد كـاهش معنىى دارى را نشان داد (جدول ^).

\section{تجزيه كلاستر}

تجزيه كلاستر بر اساس ها إفت مورد مطالعه در سـطح شـورى ז ا دسىزيمنس بر متر انجام شد و باعث تشكيل سه گـروه شـد. گروه اول كه بيانگر ارقام حساس به شورى، شـامل درگـزى، زرد ايوانكى و كنكى است. در شورى با ا دسىزيمنس كمترين ميـزان

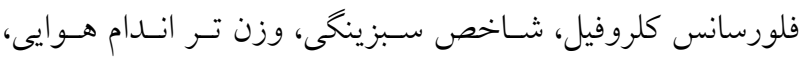

بر متر نسبت به شاهد افزايش معنىدارى نشان ندادند اما در بقيه تيمارها نسبت به شاهد افـزايش معنسى دارى نشـان دادنـد. رقـم دياموند فقط در تيمار r| دسى زيمنس بر متر افزايش معنسىدار را نشان داد. غلطـت يــون يتاسـيم بـا اعمــال شـورى در ارقـام

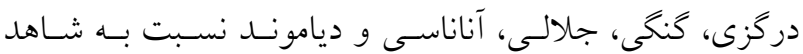
كــاهش معنــــدارى نشـــان داد. رقـــم سوســــى در تيمـــار 9/9 دسىزيمنس بر متر نسبت بـه شـاهد كـاهش معنسى دارى را نشان نداد و در بقيه تيمارها معنى دار بود. بيشترين ميزان كاهش

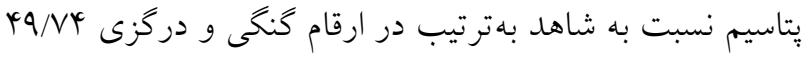

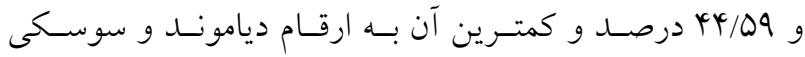

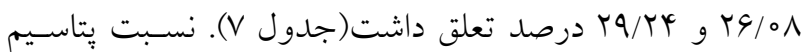


جدول V. نتايج مقايسه ميانگين اثر متقابل شورى و ارقام مختلف خربزه بر سديم و يتاسيم برى

\begin{tabular}{|c|c|c|c|c|c|c|c|c|}
\hline \multicolumn{4}{|c|}{ يتاسيم (mg/gDW) } & \multicolumn{5}{|c|}{ سديم (mg/gDW) } \\
\hline \multicolumn{4}{|c|}{ شورى (dS m } & \multicolumn{5}{|c|}{ شورى (dS m } \\
\hline ir & $\wedge$ & $9 / 9$ & صفر & ir & $\wedge$ & $9 / 9$ & صفر & ارقام \\
\hline $19 / \Lambda \mu^{t-u}$ & $r G / T V^{\mathrm{m}-\mathrm{u}}$ & $r q / I V^{f-s}$ & $r \Delta / v q^{c-1}$ & $91 / 19^{a-c}$ & $01 / 90^{c-g}$ & $r \Lambda / \mu^{r-v}$ & $r V / \Gamma \Lambda^{s-b}$ & درگزى \\
\hline$r \Delta / 9 \Lambda^{n-u}$ & $r V / 99 \mathrm{~h}-\mathrm{t}$ & $T Y / \Lambda Y^{\mathrm{p}-\mathrm{u}}$ & $r q / v q^{b-d}$ & $\Delta r / \mu^{c-f}$ & $\varphi 9 / 9 V^{\mathrm{e}-\mathrm{g}}$ & $\mathrm{rV} / 10^{\mathrm{i}-\mathrm{s}}$ & $r q / \Delta^{p-v}$ & خاتونى \\
\hline YQ/YY o-u & $r 9 / 99^{1-u}$ & $r G / \Delta V^{m-u}$ & $r \Delta / r \Delta^{c-m}$ & $\hat{\kappa} \wedge / N \mu^{\mathrm{d}-\mathrm{h}}$ & FY/Vq $\mathrm{f}-\mathrm{n}$ & 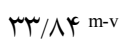 & $Y Y / Q$ uv & عباس شورى \\
\hline$r \Delta / \mu_{1}$ o-u & $T r / 09 d-q$ & $r q / T \wedge$ f-s & $\mathrm{rV} / 9 \mathrm{~V}$ b-f & $91 / 0 V V^{a-c}$ & $\Gamma \Delta / \Lambda^{k-t}$ & $r y / q r^{e-1}$ & $r \mu / 9 T^{v}$ & جاه پِاليز \\
\hline$r y / / q-u$ & $r N / Y^{h-t}$ & $r y / V I c-n$ & TN/MYTh-t & $90 / 1)$ ab & $\Delta \mathrm{r} / 9 q^{\mathrm{c}-\mathrm{e}}$ & $r N / D 1^{\text {h-q }}$ & $T V / F T^{s-V}$ & زرد ايو انكى \\
\hline$r Y /\left.4\right|^{r-u}$ & TV/TY k-u & $r V / F V^{b-g}$ & $r \Delta / \Lambda r^{c-1}$ & $91 / 0^{a-c}$ & $\nvdash \vee / \wedge \Delta^{d-h}$ & $r q / \circ q^{i-s}$ & rG/AYs-v & كر كاب \\
\hline$|N / \Delta|^{\prime} u$ & $r \varphi / T V^{m-u}$ & $\boldsymbol{r}^{\prime} / \mathcal{A N}^{\mathrm{d}-\mathrm{r}}$ & rq/1 $99^{c-1}$ & $V I / \mathbb{H}^{\mathrm{a}}$ & $\$ \varphi / 9 q e^{e-j}$ & rG/VG e-k & $r \Delta / \Gamma^{t-v}$ & 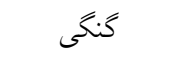 \\
\hline$Y V / V Y^{\mathrm{j}-\mathrm{t}}$ & $\mathrm{r} / \mathrm{\Delta \Lambda} \mathrm{d}-\mathrm{q}$ & $Y N / Y^{\prime} V^{g-t}$ & $\varphi \circ / \Gamma \Lambda^{b-d}$ & $\mathcal{Y} N / \Delta \wedge \mathrm{d}-\mathrm{h}$ & $r Y^{\prime} / V^{1-u}$ & $\uparrow \varphi / r q$ uv & $r q / \varphi \&$ p-v & صادراتى \\
\hline$r V / r \Delta^{j-t}$ & $r / T^{d-q}$ & rN/VA b-e & TV/AS ${ }^{\mathrm{i}-\mathrm{t}}$ & $01 / 900^{c-g}$ & $\hat{i} \wedge /\left.1\right|^{\mathrm{d}-\mathrm{h}}$ & $r Q / \circ \wedge p^{p-v}$ & $r T / \circ q^{O-v}$ & يوست زرد \\
\hline TV/V ' k-u & $\forall / / D b c$ & $r_{0} / / r^{\mathrm{e}-s}$ & $0 \circ / 9 r^{\text {a }}$ & $\mathcal{F V} / T V^{\mathrm{d}-\mathrm{i}}$ & $r \mu / q \varphi^{e-m}$ & $\mu_{0} / 9 \mu^{q}-v$ & $r Q / 9 V^{t-V}$ & سبز اصفهان \\
\hline$Y V / V Y^{\mathrm{j}-\mathrm{t}}$ & $r q / 9$ f-s & $r \varphi / l V^{c-o}$ & $\langle\varphi / 4 i$ ab & $\Delta V / \& q^{b-d}$ & $r N / q^{\mathrm{r}-\mathrm{v}}$ & $\mathrm{rN} / \Delta \mathrm{Q}^{\mathrm{m}-\mathrm{v}}$ & $r \psi / q r^{\mathrm{e}-1}$ & جالى \\
\hline$r q /\left.4\right|^{f-s}$ & $Y N / Y^{\mathrm{h}-\mathrm{t}}$ & $r q /\left.\circ\right|^{f-s}$ & re/VG c-j & $\Delta r / \mathbb{F}^{\mathrm{c}-\mathrm{f}}$ & $F Y / T^{g-0}$ & 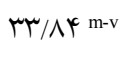 & $r q / / V^{p-v}$ & قصرى مشهلى \\
\hline$r r / \Delta Y q^{-u}$ & 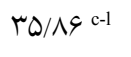 & $r \Delta / 9 r^{c-1}$ & $M V / Y^{c b-g}$ & 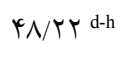 & $r G / 4 V^{j-s}$ & $\mathrm{~m} / 99^{\mathrm{m}-\mathrm{v}}$ & $r_{0} / / V^{p-v}$ & آناناسى \\
\hline$r \varphi / T Y^{\mathrm{m}-\mathrm{u}}$ & $r 9 / 90$ f-s & ra/Mr c-k & $\mathrm{rV} / \circ 9^{\mathrm{c}-\mathrm{h}}$ & $\kappa r / 1 \varphi^{\mathrm{e}-\mathrm{n}}$ & $r q /\left.\mu\right|^{\text {h-p }}$ & $T / /\left.\Delta\right|^{p-v}$ & $Y Y / Q$ uv & \\
\hline$r \mid / T^{\text {s-u }}$ & $r \Delta / V Q^{n-u}$ & TY/AY p-u & & $\Delta \circ /{ }^{\wedge} \wedge \mathrm{d}-\mathrm{g}$ & 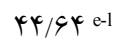 & rG/Or s-v & rN/YY h-r & خاقانى \\
\hline$r q / \wedge q^{k-u}$ & $r \circ / V^{\text {e-s }}$ & r c-p & 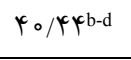 & $k \psi / 0 \mid e-m$ & $r \mathrm{r} / 9 \mathrm{~V}$ n-v & $M r / G V$ p-v & $r \wedge^{r-v}$ & دياموند \\
\hline & $9 / 10$ & & & & & $10 / 94$ & & LSD $\% 5$ \\
\hline
\end{tabular}

جدوله. نتايج مقايسه ميانخين اثرات متقابل شورى و ارقام مختلف خربزه بر يتاسيم به سديم برگ (mg/gDW)

\begin{tabular}{|c|c|c|c|c|}
\hline \multicolumn{5}{|c|}{ شورى (dS m } \\
\hline IT & $\wedge$ & $9 / 9$ & صفر & ارقام \\
\hline$\circ / Y^{x y}$ & $0 /\left.0\right|^{s-y}$ & $1 / \circ \mu^{e-1}$ & $1 / r b^{a-f}$ & درگزى \\
\hline $0 / 4 q^{t-y}$ & $0 / 9^{n-y}$ & $0 / 9 V^{1-x}$ & $1 / \mu y^{a-f}$ & خاتونى \\
\hline$\circ /\left.D\right|^{s-y}$ & $0 / 9 Y^{\mathrm{m}-\mathrm{y}}$ & $\circ / \wedge D^{i-t}$ & $1 / 4 y$ a-d & عباس شورى \\
\hline $0 /\left.4\right|^{v-y}$ & $\circ / 90^{h-o}$ & $0 / 9 y^{4} \mathrm{~m}-\mathrm{x}$ & $1 / 9 Y^{a}$ & جاه پِاليز \\
\hline ० R w w-y & $\circ / \Delta Y^{s-y}$ & $1 / \circ Y^{f-1}$ & $1 / 1^{c-k}$ & زرد ايوانكى \\
\hline$\circ N^{w-y}$ & $0 / \Delta \& q^{q-y}$ & $0 / 99^{g-0}$ & 1/א a-g & كر كاب \\
\hline $0 / \varphi^{y}$ & $0 / 9^{\mathrm{m}-\mathrm{y}}$ & $0 / M^{i-s}$ & $1 / 4 \varphi^{a-c}$ & كنگ \\
\hline$\circ / Q \vee p-y$ & $\circ / q r^{h-q}$ & $0 / 99^{1-x}$ & $1 / 4^{a-e}$ & صادراتى \\
\hline$\circ / \Delta \Delta^{r-y}$ & $\circ / 99^{1-w}$ & $1 / \Delta D^{a b}$ & $\circ / \Lambda^{i-s}$ & يوست زرد \\
\hline $0 / 090-y$ & $0 / 99 \mathrm{~g}-\mathrm{m}$ & $\circ / 99$ f-m & $1 / 1 k^{c-j}$ & سبز اصفهان \\
\hline $0 / 4 \Lambda^{t-y}$ & $1 / 0 V^{d-k}$ & $1 / 19^{b-i}$ & $1 /\left.\right|^{k-j}$ & جلالى \\
\hline $0 / 094-y$ & $0 / 99^{\text {l-w }}$ & $0 / A r^{i-t}$ & $1 / T Q^{a-h}$ & قصرى مشهدى \\
\hline$\circ / q^{j-u}$ & $1 / \circ Y^{f-1}$ & $1 / \circ V^{c-k}$ & $1 / T V^{a-h}$ & آناناسى \\
\hline $0 / 91^{\text {n-y }}$ & $\circ / N Q^{k-v}$ & $1 / 19^{c-1}$ & $1 / \wedge^{b-i}$ & سوسكى \\
\hline $0 / 4 F u-y$ & $\circ / \Delta 9^{\text {n-y }}$ & $0 / 9 \psi^{\text {h-p }}$ & $\circ /\left.9\right|^{\text {h-r }}$ & خاقانى \\
\hline$\circ / \vee^{j-u}$ & $\circ / 99^{\mathrm{f}-\mathrm{m}}$ & $1 / 111^{c-k}$ & $1 / 4 y^{a-d}$ & دياموند \\
\hline & & $\circ / Y V$ & & $\mathrm{LSD}_{\% 5}$ \\
\hline
\end{tabular}

در هر ستون ميانكينهايى كه داراى حداقل يك حرف مشترى هستند، تفاوت معنى دارى در سطح احتمال بنج درصد بر اساس أزمون حداقل اختلاف معنىدار (LSD)، ندارند. 
به شورى نسبت سديم به يتاسيم يّايينى در اندامهاى مختلـف و

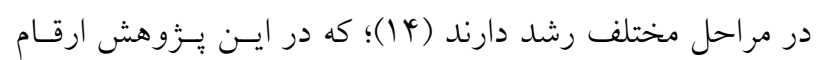

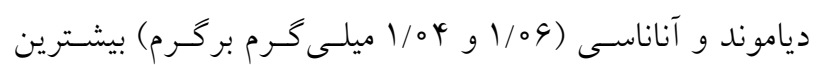

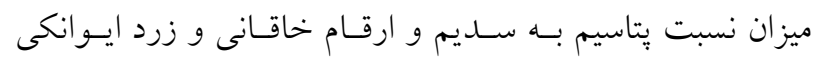

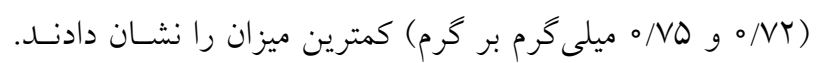
در گونههاى حساس به شورى ميزان سديم و بتاسيم تمايـل بـهـ ثابت ماندن غلظتشان دارند، درحالى كه در كونههاى متحمـل بـهـ شورى غلظت يتاسيم با افزايش جذب سديم كاهش مىيابـد تـا بتواند تنظيم اسمزى صورت گيرد و كـاهش نسـبت يتاسـيم بـه سديم برى به خاطر جذب بيشـتر بتاسـيم نسـبت بـه سـديم و

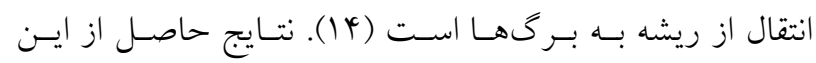

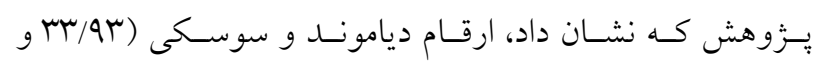

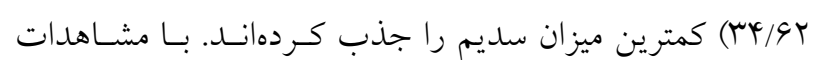
كوسواران و همكاران در بررسى تحمل به شـورى هب زنوتيـبِ خربزه كه نشان داد زنوتيِّهايى كه مقدار يون سديم كمتـرى را جذب كردهاند، در برابر شورى متحملتر هستند، مطابقـت دارد (IV). ميزان فلورسانس كلروفيل مىتواند توانايى گياه در تحمل به تنش هاى محيطى و ميزان خسـارتى كـه تسنش بـه كيـاه وارد مى كند را بهذخـوبى نشـان دهـــ. تسنش شـورى موجـب كـاهش حداكثر عملكرد كوانتومى فتوسيستم II در شرايط ساز گار شــه

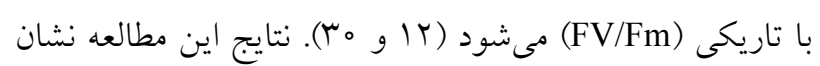
داد، با افزايش سطح شورى، ميزان فلورسانس كلروفيل در بيشتر ارقام كاهش يافت. بيشترين ميزان آن در گياهان شاهد و در رقم

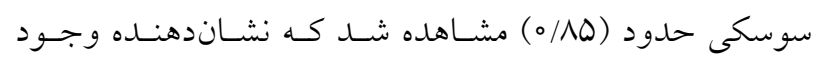
شرايط محيطى مطلوب و فاقد تــش بــراى رشــ ارقـام در كـل دوره آزمايشى بود. كمترين ميـزان آن در رقـم كنخـى (عاع/ه) و در تيمار شورى T| دسىزيمنس بر متر بود. شاخص سبزينكى بهنوان يكى از يُار امترهاى تحمل به شورى در گياهان مطرح شده اسـت. شـاخص سـبزينكى تحـت تــش شـورى كـاهش

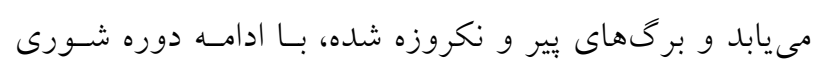

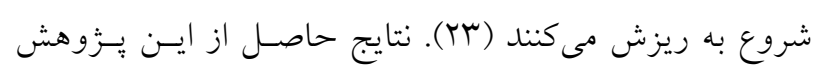

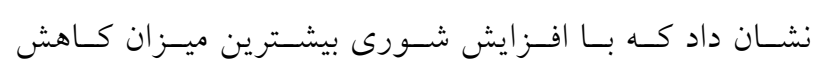

غلظت يون يتاسيم و نسبت يتاسـيم بـه ســـيم و بيشـترين ميـزان

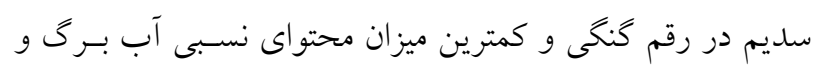

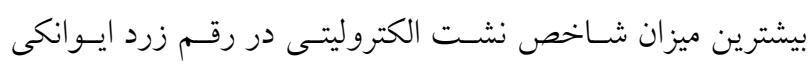

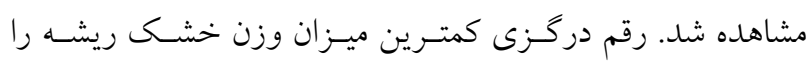

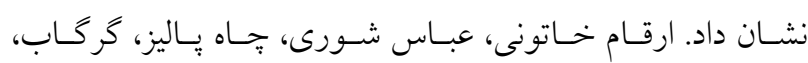
صادراتى، يوست زرد تو قرمز، جاللى، قصرى مشهلى و خاقـانى

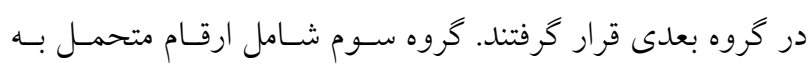
شورى، شامل سبز اصفهان، آناناسى، سوسـكى و ديامونـاسـ اسـت. بيشـرين وزن خشـك ريشـه و كمتـرين ميـزان ســـيم در رقـم سوسكى و بيشترين ميزان شاخص سبزينكى، غلظت يون يتاسـيم

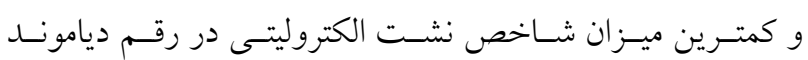
مشاهده شد. رقم سبز اصفهان بيشترين ميزان وزن تر اندام هـوايى را نشان داد. بيشترين ميزان فلورسانس كلروفيل و وزن تـر ريشـهـ به رقم آناناسى اختصاص داده شد. (شكل (1) نتايج حاصل از اين يزوهش نشان داد كـهـ تــش شـورى باعـث كاهش شاخصهاى رشدى در ارقام خربزه شد. اولـين واكـش كياه به شورى، كاهش آهنخ رشد است. گياهان در حـال رشــ در شرايط شور، سرعت رشد كمتر، برگهاى سبز تيره، كوجـك و كوتوله دارند (IV). افزايش شورى باعث افزايش ميزان سديم در انــامهــاى هـوايى و ريشـههــا و كـاهش ميـزان يتاسـيم در اندامهاى مختلف كياه شده است. در ايـن آزمـايش بــا افـزايش ميزان سطوح شورى بيشترين ميـزان افـزايش ســـيم نسـبت بـهـ

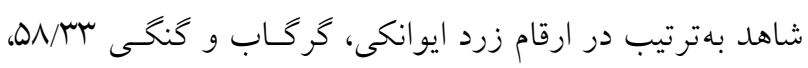

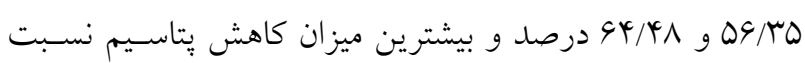

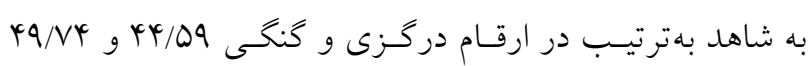

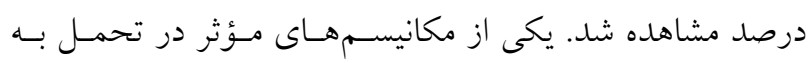

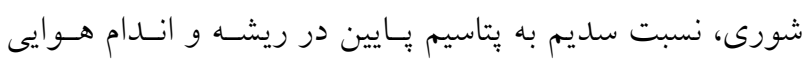

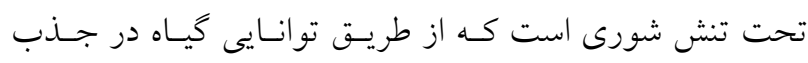
يتاسيم و جلو كيرى از ورود سديم بـه ريشـه حاصـل مسى شــود. به كونهاى كه ارقام مقاوم به شورى در مقايسه با ارقـام حسـاس 
Dendrogram

Ward's Method,Euclidean

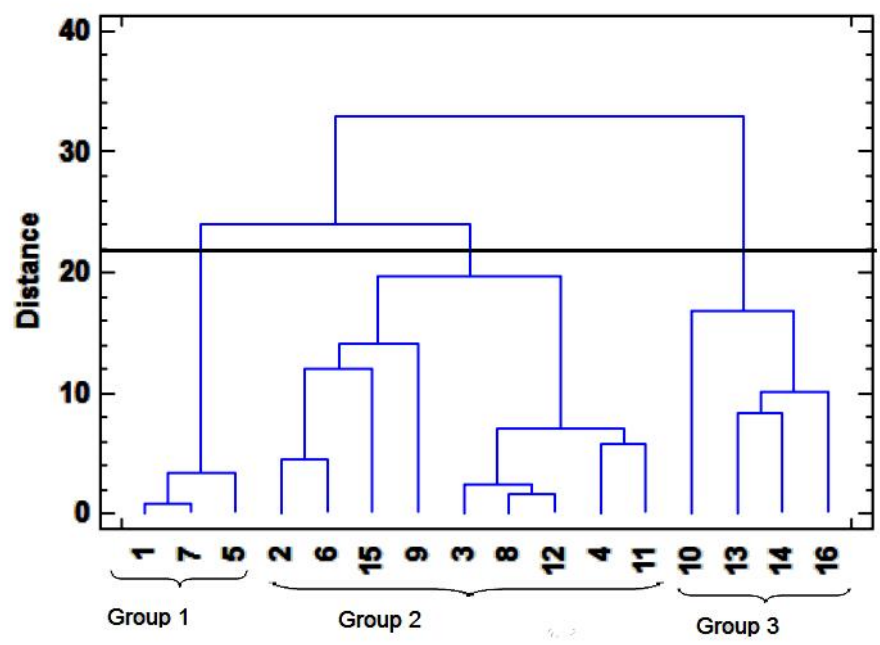

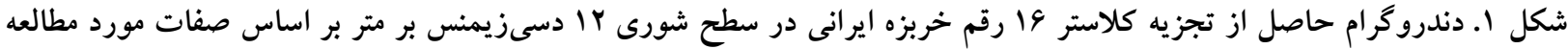

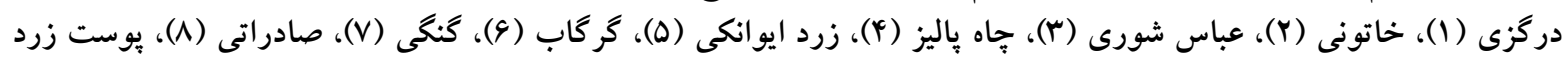

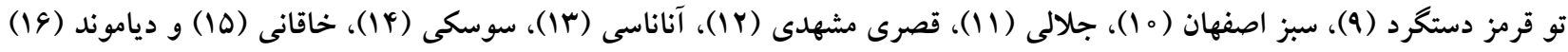

در محتواى كلروفيـل درنتيجهـه شـورى در مـورد كـلدوتنبل هـم كزارش شده است كـهـ بـا نتـايج مـا مطابقـت دارد (YV). تــش اكسيداتيو ناشى از شورى موجب بر اكسيداسيون جربى غشاء و

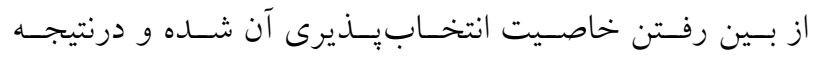
نفوذيذيرى غشاى سلولى براى يونها و الكتروليـتهــا افـزايش مىيابد. آبراهام و همكاران گزارش كردند تحت شـرايط تـشن،

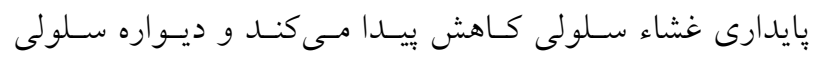
تخريب مىشود و مايع سلولى به داخل محيط تراوش مى كنـد و

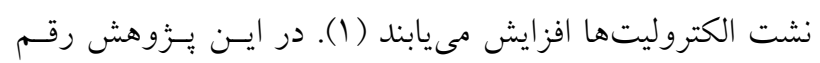
سوسكى در سطح شورى صفر (شاهد) كمترين ميـزان شـاخص

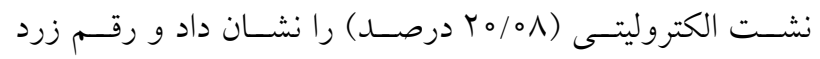
ايوانكى در سطح شورى rا إسىزيمنس بر متر بيشترين ميـزان (צ/ كرد كه تحمل رقم سوسكى به تنش شـورى بـالا اسـت. نتسايج

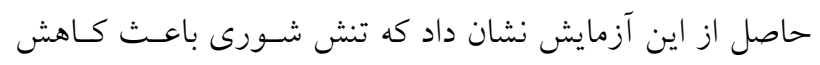
رشد ريشه، اندامهاى هوايى، كاهش وزن تر و خشك و كـاهش مقدار كلروفيل شد؛ كه با نتـايج فرانكـو و همكــاران روى گيـاه خربزه و ماروجينايولوس و همكاران در كشت كلخانسهاى، كيـاه

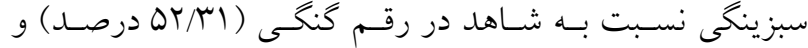
كمترين ميزان آن در رقم خاقانى (r/VN Iا درصد) مشـاهده شـد. كافى و همكاران بيان كردند كه در شرايط تنش ملايم با كـاهش سطح برى غلظـت كلروفيـل در واحـــ سـطح بـرى مسىتوانـد

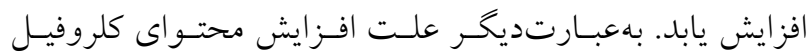
تحت تنش، كوجى شدن سلولهاى برگ به علت كاهش سطح برى و ضخيم شدن سلولها است. درحالى كه تنش شديد باعث توقف كلروفيلسازى مى شود (11) كه با نتـايج حاصـل از ايسن آزمايش مطابقت دارد. در اين آزمايش سـبزينكى در ارقـام جــاه ياليز و قصرى مشهدى در سطح شورى شش دسىزيمـسنس بـر

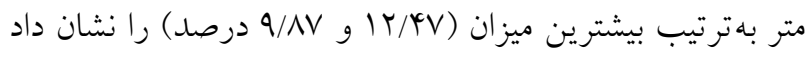
و با ايجاد تنش شديدتر، سطوح شورى (1 و r ا دسىزيمـنس بـر متـر) ميـزان سـبزينكى كـاهش يافـت. علـت كـاهش عـدد كلروفيلمتر در سطوح شورى بالاتر را مسىتـوان كـاهش ميـزان كلروفيل بهواسطه تخريب ساختار كلرويلاست عنـوان كـرد. در شر ايط شورى، رنخدانـهـهـاى كلروفيـل بــراى ثبـات انــامهــاى

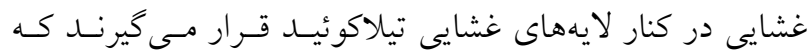
بهندرت بدون عيب و دستنخورده باقى مىمانند (YV). كـاهش 


\section{نتيجه گيرى}

بهطوركلى نتايج حاصل از اين يزّوهش نشان داد كـهـ بـا اعمـال تنش شورى و افزايش غلظت آن، شاخصهــاى رشــى شـامل كلروفيل فلورسـانس، شـاخص سـبزينگى، محتـواى نسـبى آب برگ، يتاسيم برى و نسبت يتاسيم به سديم و وزن تر و خشـك اندام هوايى و ريشه در تمامى ارقام مطالعه شده كاهش و درصد نشت يونى و ميزان يون سديم برى افـزايش يافتنـد. در شـرايط شور كمترين ميزان فلورسـانس كلروفيـل، شـاخص سـبزينگى، وزن تر اندام هوايى، غلظت يـون بتاسـيم و نسـبت يتاسـيم بــه سديم و بيشترين ميزان سديم در رقم كنخى و كمتـرين ميسزان

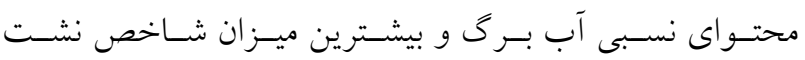

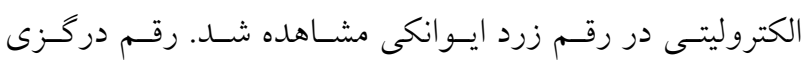
كمترين ميزان وزن خشك ريشـه را نشـان داد. بيشـترين ميـزان فلورسانس كلروفيل، وزن تر و خشك ريشه در رقم سوسكى و بيشترين ميزان شاخص سبزينگى و كمترين ميزان شاخص نشت الكتروليتى در رقـم ديامونــد مشـاهده شـد. رقـم سـبز اصـفهان بيشترين ميزان وزن تر اندام هوايى غلظت يون يتاسـيم را نشـان داد. بر اساس نتايج به دست آمده مىتوان عنوان كـرد كـه ارقـام مورد بررسى بر اساس صفات مطالعه شده به دو گـروه حسـاس

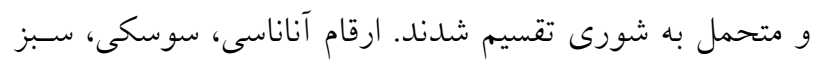
اصفهان و دياموند متحمل ترين و ارقام درگـزى، زرد ايـوانكى و كنگى حساسترين ارقام تشخيص داده شد.
طالبى مطابقت دارد (V و م Y). بيشترين و كمترين ميزان كـاهش

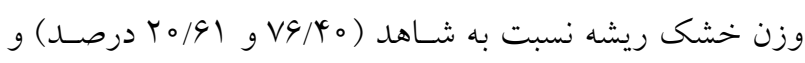

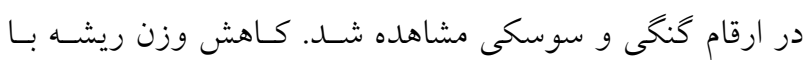
افزايش شورى مى تواند بهدليل سميت يـونى و كـاهش بتانسـيل آب در ناحيه ريشه باشد. در شـرايط تسنش شـورى گيـاه بـراى جلو گيرى از ورود بيشازحد يون سديم به داخـل ريشـه مقــدار زيادى انرزى مصرف مى كند كه ايسن امـر باعـث كـاهش رشــ ريشه مىشود (YY). در شرايط شور، كاهش در ميـزان كلروفيـل از يك سو و آثار سمى يونهـاى كلـر و سـديم از سـوى ديخـر باعث اختلال در فعاليت فتوسـتنزى گيـاه مسىشـود و درنتيجـه باعث كاهش در وزن تر و خشك كيـاه مسى شـود ( آT). در ايسن آزمايش بالاترين ميزان محتواى نسبى آب بـرى در ارقـام سـبز اصفهان و سوسكى مشاهده شد. با افزايش ميزان سطوح شـورى بيشترين ميزان كاهش محتواى نسبى آب برى نسبت بـه شـاهد

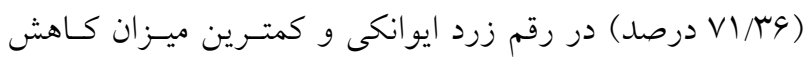
نسبت به شاهد ( YN/D درصد) و در رقم سبز اصفهان مشـاهده شد. بالا بودن ميزان درصد محتواى آب نسبى در زنوتيـٍِهـاى متحمل به تنش مىتواند بهدليل وجود برخى از عوامل كم كننده

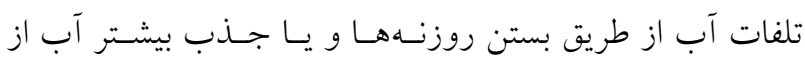

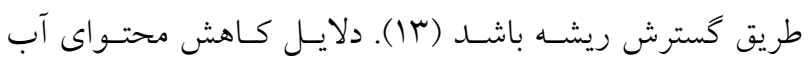
نسبى در شرايط تنش مىتوان به كاهش بتانسـيل آب بـرى كـه خود منجر بـه كـاهش تورزسـانس، هـدايت روزنـهاى و ميـزان

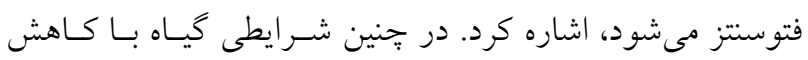
رشد و درنتيجه كاهش عملكرد مواجه مىشود (1 أ).

\section{منابع مورد استفاده}

1. Abraham, E. M., B. Huang, S. A. Bonos and W. A. Meyer. 2004. Evaluation of drought resistance for Texas bluegrass, Kentucky bluegrass, and their hybrids. Crop Science 44: 1746-1753.

2. Antcliff, A. J., H. P. Newman and H. C. Barret. 1983. Variation in chloride accumulation in some American species of grapevine. Vitis Journal of Grapevine Research 22: 357-362.

3. Arzani, A. and M. Ashraf. 2016. Smart engineering of genetic resources for enhanced salinity tolerance in crop plants. Critical Reviews in Plant Sciences 35: 146-189.

4. Bohra, J. S. and K. Doerffling. 1993. Potassium nutrition of rice (Oryza sativa L.) varieties under NaCl salinity. Plant and Soil 152: 299-303.

5. Botia, P., J. M. Navarro, A. Cerda and V. Martinez. 2005. Yield and fruit quality of two melon cultivars irrigated with saline water at different stages of development. European Journal of Agronomy 23: 243-253. 
6. Bustan, A., S. Cohen, Y. De Malach, P. Zimmermann, R. Golan, M. Sagi and D. Pasternak. 2005. Effects of timing and duration of brackish irrigation water on fruit yield and quality of late summer melons. Agricultural Water Management 74: 123-134.

7. Franco, J. A., C. Esteban and C. Rodriguez. 1993. Effects of salinity on various growth stages of muskmelon cv. Revigal. Journal of Horticultural Science 68: 899-904.

8. Hamada, A. M and A. E. EL-enany. 1994. Effect of $\mathrm{NaCl}$ salinity on growth, pigment and mineral element contents and gas exchange of broad bean and pea plants. Biologia Plantarum 36: 75-81.

9. Hanachi, S., M. C. Vanlabeke, T. Andmehouach. 2014. Application of chlorophyll fluorescence to screen eggplant (Solanum melongena L.) cultivars for salt tolerance. Photosynthetica 52: 57-62.

10. Javanmardi, J., H. Lessani and A. Kashi. 2001. Effect of different levels of sodium chloride on absorbtion and transportation of some elements in five native of Iran melon (Cucumis melo L.) cultivars. Iranian Journal of Agricultural Sciences 32: 31-40. (In Farsi).

11. Kafi, M., A. Zand, B. Kamkar, H. R. Sharifi and D. Goldani. 2001. Plant Physiology, (Translation), Published by University Jihad (Ferdowsi University of Mashhad) Mashhad. (In Farsi).

12. Kao, W. Y., T. T. Tsai and C. N. Shih. 2007. Gas exchange and chlorophyll fluorescence parameters of 10 barley genetic lines in salt stress. Field Crops Research 99: 249-251.

13. Kaya, C., A. L. Tuna, M. Asraf and H. Altunlu. 2007. Improved salt tolerance of melon (Cucumis melo L.) by the addition of proline and potassium nitrate. Environmental and Experimental Botany 60: 397- 403.

14. Kumar, A. and K. D. Sharma. 2010. Leaf water content-a simple indicator of drought tolerance in crop plants. Indian Journal of Agricultural Sciences 80: 1095-1097.

15. Kusvuran, S., F. Yasar, S. Ellialtioghu and A. Abak. 2007. Utilizing some of screening methods in order to determine tolerance of salt stress in the Melon (Cucumis melo L.). Research Journal of Agriculture and Biological Sciences 3: 40-45.

16. Kusvuran, S., S. Ellialtioglu, F. Yasar and K. Abak. 2007. Effects of salt stress on ion accumulation and activity of some antioxidant enzymes in melon (Cucumis melo L.). Journal of Food Agriculture and Environment 5: 351.

17. Kusvuran, S., S. Ellialtıglu, K. Abak and F. Yasar. 2007. Responses of some melon (Cucumis sp.) genotypes to salt stress. Journal of Agricultural Sciences 13: 395-404.

18. Laarayedh, L., R. Lamari, M. Elbekey and A. Ferchichi. 2009. Mineral analysis of some local cultivars of melon (Cucumis melo L.). Journal of Arid Land Studies 19: 189-192.

19. Lutts, S., J. M. Kinetand, J. Bouharmont. 1996. NaCl-induced senescence in leaves of rice (Oryza sativa L) cultivars differing in salinity resistance. Annals of Botany 78: 389-398.

20. Mavrogianopoulos, G. N., J. Spanakis and P. Tsikalas. 1998. Effect of carbon dioxide enrichment and salinity on photosynthesis and yield in melon. Scientia Horticulturae 79: 51-63.

21. Mimica-Dukic, N., B. Bozin, M. Sokovic, B. Mihajlovic and M. Matavulj. 2003. Antimicrobial and antioxidant activities of three Mentha species essential oils. Planta Medica 69: 413-419.

22. Mohammad Zadeh, A. 2011. Effect of Salinity irrigation water and the quantity of commercial varieties of melon, In: Proceeding of the First National Congress of Melon Production and Processing. Torbat Jam. (In Farsi).

23. Parida, K. A. and A. B. Das. 2005. Salt tolerance and salinity effects on plants: a review. Ecotoxicology and Environmental Safety 60: 324-349.

24. Rahmani, E., A. A. Jafari and P. Hedayati. 2006. Seed and hay production in 10 ecotypes of mountain rye Secale montanum in cold-temperate territory of northern Lorestan. Iranian Journal Rang Desert Research 13: 172-185. (In Farsi).

25. Pessarakli, M. 1999. Handbook of Plant and Crop Stress. Marcel Dekker Incorporation. New York.

26. Ritchie, S. W., H. T. Nguyen and A. S. Holaday. 1990. Leaf water content and gas exchange parameters of two wheat genotypes differing in drought resistance. Crop Science 30: 105-111.

27. Salehi, M., A. kochaki and D. Nasiri mahalati. 2004. The nitrogen and chlorophyll content as an indicator of salt stress in wheat. Iranian Journal Agricultural Research 2: 25-30. (In Farsi).

28. Sarmadnya, GH. and A. kochaki. 1987. Physiological Aspects of Dry Farming (Translation). Publications University of Mashhad. Mahshhad. (In Farsi).

29. Sevengor, S., F. Yasar, S. Kusvuran and S. Ellialtioglu. 2011. The effect of salt stress on growth, chlorophyll content, lipid peroxidation and antioxidative enzymes of pumpkin seedlings. African Journal of Agricultural Research 6: 4920-4924.

30. Zhao, G. Q., B. L. Ma and C. Z. Ren. 2007. Growth, gas exchange, chlorophyll fluorescence, and ion content of naked oat in response to salinity. Crop Science 47: 123-131. 


\title{
Evaluation of Responses of Iranian Melon Cultivars to Salinity Stress
}

\author{
H. Shafiee ${ }^{1}$, M. Haghighi ${ }^{*}$ and A. Farhadi ${ }^{3}$
}

(Received: May 10-2017; Accepted: April 30-2018)

\begin{abstract}
To study the response of Iranian melon cultivars to salinity stress a factorial experiment based on RCBD with 3 replications was conducted. Four salinity treatments $(0,6.6,8$ and $12 \mathrm{dS} / \mathrm{m} \mathrm{NaCl})$ and 16 muskmelon (Cucumis melo L.) cultivars namely 'Dargazi', 'Khatooni', Abbas shori', 'Chah paliz', 'Zard Ivanaki', 'Gorgab', 'Gongi', Saderati', 'Dastgerd', 'Sabz Isfahan', 'Jalali', Ghasri Mashhad', Sooski', 'Khaghani', with two imported hybrids 'Annanasi' and 'Diamond' were used. The results showed that along with increasing salinity levels to 6.6, 8, and $12 \mathrm{ds} / \mathrm{m}$, the highest increase in electrolyte leakage and $\mathrm{Na}^{+}$concentration $(45.35$ and $64.48 \%$, respectively) were observed in Gongi cultivar, compared with the control. The largest decrease in chlorophyll fluorescence was found to be $21.95 \%$ in Dargazi cultivar. Greenness index, $\mathrm{K}^{+}$concentration of leaf, $\mathrm{K}^{+} / \mathrm{N}^{+}$, fresh weight of shoot and dry weight of root were decreased by $52.31,49.74,82.19,75.45,76 \%$, respectively, in salt stressed Gongi plants. The greatest salt induced decreases in RWC (71.36\%) and fresh weight of root $(60.36 \%)$ were observed in Gongi and Zard ivanaki cultivars in comparison to the control plants. Cluster analysis divided the examined accessions to 3 groups. Sabz Isfahan, Ananasi, Sooski, and Diamond were recognized as salt-tolerant accessions which may contain tolerance genes which could be used to develop new modified cultivars with high salinity resistance. Dargazi, Zard ivanaki and Gongi were the most sensitive ones to the salinity stress.
\end{abstract}

Keywords: K/Na, Electrolyte Leakage, Dry Weight

1, 2. MSc. Student and Assistant Professor, Respectively, Department of Horticulture, College of Agriculture, Isfahan University of Technology, Isfahan, Iran.

3. Assistant Professor, Department of Research, Agricultural and horticultural group of Isfahan Research Center of Agriculture and Natural Resources, Isfahan, Iran.

*: Corresponding Author, Email: mhaghighi@cc.iut.ac.ir 